\title{
Bioenergetic analysis of cerebellar granule neurons undergoing apoptosis by potassium/serum deprivation
}

\author{
MB Jekabsons ${ }^{\star, 1,2}$ and DG Nicholls ${ }^{1}$ \\ ${ }^{1}$ Buck Institute for Age Research, 8001 Redwood Blvd., Novato, CA 94945, \\ USA \\ ${ }^{2}$ Current address: Department of Biology, University of Mississippi, 110 \\ Shoemaker Hall, University, MS 38677, USA \\ * Corresponding author: MB Jekabsons, Department of Biology, University of \\ Mississippi, 110 Shoemaker Hall, University, MS 38677, USA. \\ Tel: + 1-662-915-3998; Fax: + 1-662-915-5144; \\ E-mail: jekabson@olemiss.edu
}

Received 02.9.05; revised 02.11.05; accepted 29.11.05; published online 20.1.06 Edited by P Nicotera

\begin{abstract}
Apoptosis induced by $\mathrm{K}^{+}$/serum deprivation (low $\mathrm{K}^{+}$) in cerebellar granule neurons has been extensively investigated. The mitochondria play a key role in apoptosis by releasing proapoptotic factors into the cytoplasm, and mitochondrial dysfunction has been proposed as an early or initiating event in this model. To directly test this hypothesis, cellular and mitochondrial bioenergetics were quantified by determining the respiratory parameters of coverslip-attached neurons. While oxidative phosphorylation rate decreased $39-49 \%$ in low $\mathrm{K}^{+}$, this was due to decreased cellular ATP demand rather than impaired ATP/ADP exchange or respiratory chain inhibition. From 3 to $5 \mathrm{~h}$ in low $\mathrm{K}^{+}$, apoptosis progressed from 13 to $40 \%$ despite no appreciable change in respiratory parameters. Changes in steady-state $\mathrm{O}_{2}^{-}$, assessed with dihydroethidium, were seen in granule but not hippocampal neurons. The $\mathrm{O}_{2}^{-}$change correlated with changes in $\left[\mathrm{Ca}^{2+}\right]_{c}$, but not mitochondrial respiration. Thus, early mitochondrial dysfunction can be excluded in this common model of neuronal apoptosis.
\end{abstract}

Cell Death and Differentiation (2006) 13, 1595-1610.

doi:10.1038/sj.cdd.4401851; published online 20 January 2006

Keywords: mitochondria; apoptosis; cerebellar granule neuron; superoxide; brevetoxin; tetrodotoxin; dihydroethidium

Abbreviations: CGN, cerebellar granule neuron; DHE, dihydroethidium; FBS, fetal bovine serum; BSA, bovine serum albumin; TTX, tetrodotoxin; BTx, brevetoxin; $\Delta \psi_{\mathrm{p}}$, plasma membrane potential; $\Delta \psi_{\mathrm{m}}$, mitochondrial membrane potential; $\Delta p$, protonmotive force; $\mathrm{O}_{2}^{-}$, superoxide anion; FCCP, carbonyl cyanide $p$-(trifluoromethoxy) phenylhydrazone; $\left[\mathrm{Ca}^{2+}\right]_{\mathrm{c}}$, cytoplasmic $\mathrm{Ca}^{2+}$ concentration

\section{Introduction}

Cerebellar granule neurons (CGNs) undergo apoptosis when cultured in a medium containing a physiological potassium concentration (3.5-5 mM; low $\mathrm{K}^{+}$medium), and to prevent this cells are routinely cultured with $25 \mathrm{mM} \mathrm{KCl}$ (high $\mathrm{K}^{+}$ medium). Developmental expression of the plasma membrane two-pore domain TASK $\mathrm{K}^{+}$channel correlates with the susceptibility to low $\mathrm{K}^{+}$apoptosis. ${ }^{1}$ These channels are responsible for the standing outward $\mathrm{K}^{+}$current in resting cells $^{1-3}$ and when expressed the transition from high to low $\mathrm{K}^{+}$hyperpolarizes the plasma membrane from about -36 to $-75 \mathrm{mV} .^{1}$ Despite extensive research, the mechanism by which this hyperpolarization initiates apoptosis remains obscure. In view of reports of early mitochondrial dysfunction, ${ }^{4}$ cytochrome $c$ release ${ }^{5,6}$ and metabolic inhibition ${ }^{7}$ in low $\mathrm{K}^{+}$ apoptosis, and because of the organelle's participation in the intrinsic mitochondrial apoptotic pathway, ${ }^{8}$ it is important to test the hypothesis that mitochondrial bioenergetic modification is an early event preceding large-scale apoptosis. The development of the cell respirometer ${ }^{9}$ allowing quantification of in situ mitochondrial respiration in coverslip-attached neurons greatly facilitates such a study.

The intrinsic mitochondrial pathway involves translocation of proapoptotic proteins (e.g., BAX, tBid) from the cytoplasm to mitochondria, with subsequent release of resident proapoptotic proteins from mitochondria. ${ }^{8}$ Recently tBid was shown to impair ADP-stimulated mitochondrial respiration ${ }^{10}$ and to inhibit VDAC conductance in planar lipids. ${ }^{11}$ Impaired ATP/ADP exchange due to VDAC closure has been suggested as an early event in apoptosis triggered by growth factor withdrawal. ${ }^{12}$ Additionally, growth factor withdrawal may affect metabolism, suggesting a link between proapoptotic proteins, mitochondria, and cell energetics. ${ }^{13}$

Based on these studies, we performed experiments to test hypotheses related to CGN apoptosis and mitochondrial function. First, that switching from high $\mathrm{K}^{+}$medium with serum to low $\mathrm{K}^{+}$medium without serum affects CGN metabolism and mitochondrial bioenergetics. Specifically, we wanted to determine if low $\mathrm{K}^{+}$medium affects cell ATP turnover and/or maximal glycolytic supply of substrate to mitochondria. Second, that mitochondrial dysfunction is an early event preceding large-scale apoptosis, focusing on impaired ATP/ADP exchange, respiratory chain inhibition, and uncoupling.

\section{Results}

Basal neuronal respiration decreases immediately in low K-medium

The cell respirometer allows continuous monitoring of mitochondrial respiration as CGNs are transferred from a high to low $\mathrm{K}^{+}$medium (Figure 1a and $\mathrm{c}$ ). Respiration dropped immediately upon low $\mathrm{K}^{+}$exposure; this lower rate was maintained for at least $3 \mathrm{~h}$ and was reversible on restoring high $\mathrm{K}^{+}$medium since the final high $\mathrm{K}^{+}$respiration was not significantly different from the initial rate (paired Student's $t$-test; $P=0.31$ ). Neither 1 nor $3 \mathrm{~h}$ exposure to low $\mathrm{K}^{+}$ 

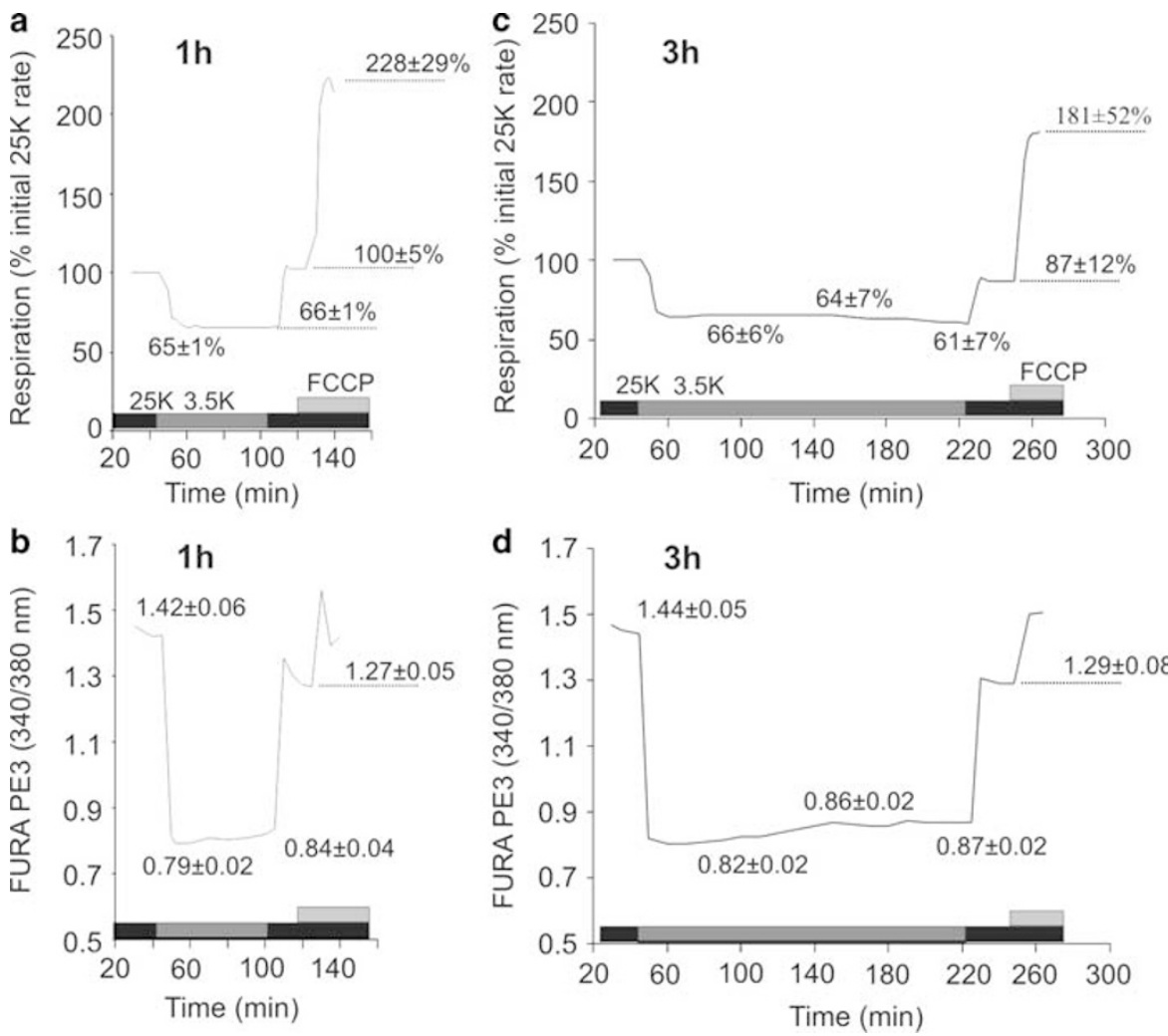

Figure 1 Cell respiration and cytoplasmic $\mathrm{Ca}^{2+}$ are decreased in low $\mathrm{K}^{+}$. Coverslips with three million CGNs (6-9 DIV) were preloaded with FURA PE3-AM plus $\mathrm{TMRM}^{+}$and assembled into the respirometer as described in Materials and Methods. Cells were perfused sequentially with high $\mathrm{K}^{+}$media $(25 \mathrm{~K})$ or, low $\mathrm{K}^{+}$media $(3.5 \mathrm{~K})$ for $1 \mathrm{~h}(\mathbf{a}, \mathbf{b})$ or $3 \mathrm{~h}(\mathbf{c}, \mathbf{d})$, followed by return to high $\mathrm{K}^{+}$. FCCP $(3 \mu \mathrm{M})$ was added to assess maximal respiration. Respiration data were normalized to the initial rate in high $\mathrm{K}^{+}$. In (a and $\mathbf{c}$ ), basal $25 \mathrm{~K}$ respiration averaged $1.26 \pm 0.26$ and $1.25 \pm 0.23 \mathrm{nmol} \mathrm{O} / \mathrm{min} \times 10^{6}$ cells, respectively. Cytoplasmic $\mathrm{Ca}^{2+}$ was expressed as the $340: 380 \mathrm{~nm}$ ratio. For each experiment, 20 regions of interest representing cell bodies were selected for FURA PE3 analysis and their ratios were averaged. Values represent mean \pm S.E.M of three experiments. Values along traces show rates $(\mathbf{a}, \mathbf{c})$ and ratios $(\mathbf{b}, \mathbf{d})$, respectively

significantly affected the reserve respiratory capacity assessed with $p$-(trifluoromethoxy) phenylhydrazone (FCCP) once cells were returned to high $\mathrm{K}^{+}$(see Figure 3 for control high $\mathrm{K}^{+}$data). Cytoplasmic $\mathrm{Ca}^{2+}\left(\left[\mathrm{Ca}^{2+}\right]_{\mathrm{c}}\right)$, as monitored with FURA PE3, changed in parallel with respiration (Figure 1b, d).

As in Figure 1, low $\mathrm{K}^{+}$is frequently coupled with serum deprivation in apoptotic studies. To distinguish between the effects of $\mathrm{K}^{+}$and serum deprivation, cells were perfused for $3 \mathrm{~h}$ with buffers that were lacking one or both components (Figure 2). Serum replacement by $0.4 \%$ bovine serum albumin (BSA) (Figure 2a) and $\mathrm{K}^{+}$removal (Figure $2 \mathrm{~b}$ ) both reduced respiration, and the effects were additive in combined $\mathrm{K}^{+}$/serum removal (Figure $2 \mathrm{c}$ ), with $\mathrm{K}^{+}$removal accounting for about $60 \%$ of the reduction. Since the serum is dialyzed against $150 \mathrm{mM} \mathrm{NaCl}$, buffers supplemented with serum had an additional $15 \mathrm{mM} \mathrm{NaCl}$ compared to those with BSA. From a control experiment (see Table 1), it was found that the acute reduction in high $\mathrm{K}^{+}$respiration upon transfer from serum to BSA was primarily due to the reduced $\mathrm{NaCl}$ and not to serum components. However, with long-term serum deprivation mitochondrial respiration was impaired (Table 1).

Cytoplasmic $\mathrm{Ca}^{2+}$ drops precipitately with $\mathrm{K}^{+}$/serum deprivation (Figure $1 \mathrm{~b}$ and $\mathrm{d}$ ). This drop is due to $\mathrm{K}^{+}$rather than to serum deprivation, as cells perfused with low $\mathrm{K}^{+}$show the same FURA PE3 reduction with and without serum (not shown). Reduced $\left[\mathrm{Ca}^{2+}\right]_{\mathrm{C}}$ may negatively regulate substrate oxidation reactions, thereby lowering respiration. However, since FCCP stimulated respiration to the same extent in both high and low $\mathrm{K}^{+}$(Figure 2 ), the respiratory reduction in low $\mathrm{K}^{+}$cannot be attributed to an inhibition of substrate supply or respiratory capacity by decreased $\left[\mathrm{Ca}^{2+}\right]_{c}$.

\section{Decreased respiration in low K-media is due to decreased ATP synthesis}

Cell respiration can be divided into mitochondrial and the nonmitochondrial oxygen-consuming reactions, and mitochondria consume oxygen to support both ATP synthesis and the endogenous $\mathrm{H}^{+}$leak. Basal cell respiration is therefore the sum of that required for mitochondrial ATP synthesis, the mitochondrial $\mathrm{H}^{+}$leak, and non-mitochondrial reactions. To determine which of these components is affected by low $\mathrm{K}^{+}$, cells were treated with oligomycin (to inhibit ATP synthase), followed by the combination of myxothiazol/ rotenone to inhibit electron transfer (Figure 3a). Using this approach, it was established that mitochondrial ATP synthesis was the only component of basal respiration significantly 

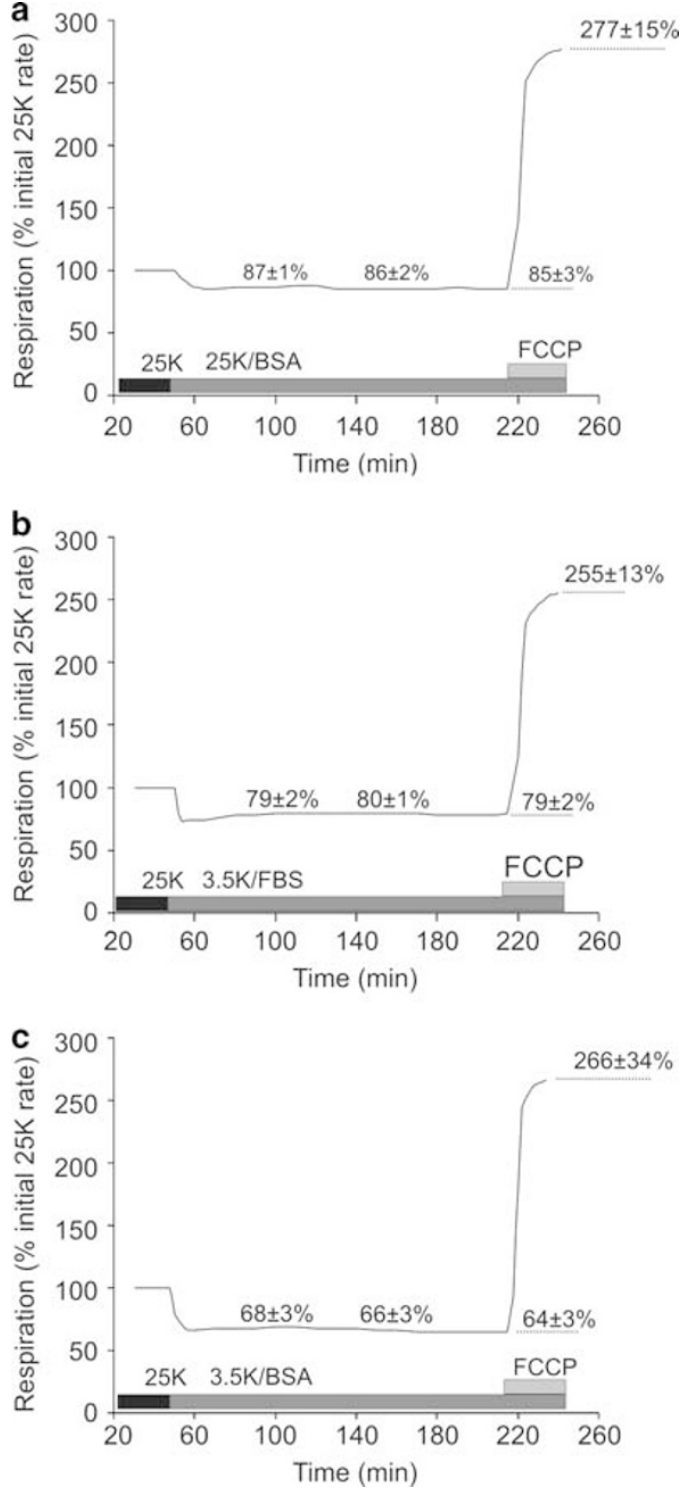

Figure 2 Serum and $\mathrm{K}^{+}$deprivation additively affect basal respiration without influencing maximal respiration. Experiments were performed as described in Figure 1. Cells were initially equilibrated in standard high $\mathrm{K}^{+}$media $(25 \mathrm{~K})$. This was followed by $3 \mathrm{~h}$ perfusion with (a) high $\mathrm{K}^{+}$media containing $0.4 \% \mathrm{BSA}$, no serum (25 K/BSA); (b) low $\mathrm{K}^{+}$media containing $10 \%$ dialyzed serum, no BSA (3.5 K/FBS), or (c) standard low $\mathrm{K}^{+}$media (3.5 K/BSA). Finally, either $3 \mu \mathrm{M}(\mathbf{b})$ or $9 \mu \mathrm{M}(\mathbf{a}, \mathbf{c})$ FCCP was added to assess maximal respiration. Values are either mean + S.D. of two experiments $(\mathbf{a}, \mathbf{b})$ or mean + S.E.M. of four experiments $(\mathbf{c})$ and reflect 1,2 , and $3 \mathrm{~h}$ basal rates, and maximal respiration in the respective buffers. Basal respiration averaged $1.07 \pm 0.44 \mathrm{nmol} 0 / \mathrm{min} \times 10^{6}$ (a), $1.29 \pm 0.24 \mathrm{nmol} \mathrm{O} / \mathrm{min} \times 10^{6}(\mathbf{b})$, and $1.93 \pm 0.62 \mathrm{nmol} \mathrm{O} / \mathrm{min} \times 10^{6}(\mathbf{c})$ cells

reduced after 1 and $3 \mathrm{~h}$ low $\mathrm{K}^{+}$(Figure $3 \mathrm{~b}, \mathrm{c}$ ). This result did not appreciably change after $5 \mathrm{~h}$ low $\mathrm{K}^{+}$. ATP synthesis was reduced by $39 \pm 3$ and $49 \pm 6$ and $40 \%$ at 1,3 , and $5 \mathrm{~h}$, respectively. Thus, low $\mathrm{K}^{+}$respiration decreases entirely as a result of a reduction in mitochondrial ATP synthesis.

The cells retained a large reserve ATP generating capacity for $3 \mathrm{~h}$ which decreases after $5 \mathrm{~h}$ in low $\mathrm{K}^{+}$, as illustrated by both the spare respiratory chain capacity evoked by FCCP (Figure 3 ) and the classical respiratory control ratio (RCR) defined as the FCCP rate divided by the oligomycin rate, corrected for non-mitochondrial respiration. Values for the RCR were $11 \pm 1$ (in 25K), $15 \pm 2$ (after $1 \mathrm{~h} 3.5 \mathrm{~K}$ ) and $20 \pm 6$ (after $3 \mathrm{~h} 3.5 \mathrm{~K}$ ), followed by a decrease to 9 after $5 \mathrm{~h}$ in low $\mathrm{K}^{+}$. Because of variability between replicates the effect of low $\mathrm{K}^{+}$ treatment on RCRs was not significant $(P=0.13)$ by one-way ANOVA.

\section{Neurons in low $\mathrm{K}^{+}$can respond to an increased cytoplasmic ATP demand}

Decreased mitochondrial ATP synthesis in low $\mathrm{K}^{+}$could be due to reduced cellular ATP demand or to impaired ATP synthesis or export. We recently reported that ATP/ADP exchange is impaired in glutathione-depleted CGNs, preventing the mitochondria from responding to an increased cytoplasmic ATP demand. ${ }^{14}$ The plasma membrane $\mathrm{Na}^{+} / \mathrm{K}^{+}$ATPase is highly expressed in neurons and is capable of hydrolyzing ATP at a rate sufficient to induce near-maximal respiration when $\mathrm{Na}^{+}$re-entry into the cell is not rate-limiting, that is, in the presence of $\mathrm{Na}^{+}$channel openers. ${ }^{15}$ Thus in high $\mathrm{K}^{+}$medium, $2 \mu \mathrm{M}$ veratridine induced $\mathrm{Na}^{+}$cycling sufficient to utilize most of the reserve mitochondrial ATP-generating capacity (Figure 4a). In contrast, after $1 \mathrm{~h}$ (not shown) or $3 \mathrm{~h}$ incubation in low $\mathrm{K}^{+}$medium (Figure $4 \mathrm{~b}$ ), veratridine failed to increase respiration even back to the basal high $\mathrm{K}^{+}$rate. While this was at first sight consistent with impaired ATP/ADP exchange, it is important to consider the mechanism of veratridine action.

As an open-channel activator, veratridine prevents $\mathrm{Na}^{+}$ channel closing but does not induce opening. Its action is therefore dependent upon spontaneous $\mathrm{Na}^{+}$channel flickering, and since the probability of $\mathrm{Na}^{+}$channel opening decreases substantially in low $\mathrm{K}^{+}$due to plasma membrane hyperpolarization, the small veratridine respiratory response in this medium may reflect reduced $\mathrm{Na}^{+}$channel activation rather than impaired ATP/ADP exchange. This was investigated with brevetoxin (BTx), a voltage-independent $\mathrm{Na}^{+}$ channel opener. ${ }^{16}$ After cells had been exposed to low $\mathrm{K}^{+}$for $3 \mathrm{~h}, 100 \mathrm{nM}$ BTx increased respiration to the same extent as in high $\mathrm{K}^{+}$controls (Figure $4 \mathrm{c}, \mathrm{d}$ ), indicating that the ineffectiveness of veratridine in low $\mathrm{K}^{+}$was due to an inability to open channels and did not indicate impaired ATP/ADP exchange. Consistent with this, when cells were briefly returned to high $\mathrm{K}^{+}$after $3 \mathrm{~h}$ low $\mathrm{K}^{+}$, veratridine robustly stimulated respiration (Figure 4e). Taken together, these data show that mitochondrial ATP synthesis is reduced in low $\mathrm{K}^{+}$ because ATP demand within the cell decreases, not because of impaired ATP/ADP exchange.

One predicted consequence of reduced ATP turnover is reduced glycolytic flux. When glucose is replaced with pyruvate as substrate, oxidative phosphorylation, and hence respiration, will increase to compensate for the deficit in glycolytic ATP production (Figure 5). On this basis glycolysis accounted for 8 and $12 \%$ of total basal ATP production in high and low $\mathrm{K}^{+}$media, respectively. The absolute glycolytic ATP synthesis rate decreased slightly (about $20 \%$ ) in low $\mathrm{K}^{+}$, consistent with reduced ATP demand. 
Table 1 Cell respiration, cytoplasmic $\mathrm{Ca}^{2+}$, and morphology of $\mathrm{CGNs}$ during $5 \mathrm{~h}$ perfusion with buffers differing in serum, $\mathrm{KCl}$ or $\mathrm{CaCl}{ }_{2}$

\begin{tabular}{|c|c|c|c|c|c|c|c|}
\hline & $25 K$ & $25 \mathrm{~K} / \mathrm{BSA}$ & $25 \mathrm{~K} / \mathrm{BSA} / \mathrm{NaCl}$ & $25 \mathrm{~K} / 0.02 \mathrm{Ca}^{2+}$ & $3.5 \mathrm{~K}$ & $10 K$ & $15 K$ \\
\hline \multicolumn{8}{|c|}{ Respiration relative to $25 \mathrm{~K}$ control } \\
\hline $1 \mathrm{~h}$ & 108 & 86 & 98 & 79 & 67 & 60 & 68 \\
\hline $2 \mathrm{~h}$ & 110 & 86 & $92(93)$ & 78 & 70 & 56 & 66 \\
\hline $3 h$ & 109 & 83 & $85(87)$ & $75(77)$ & $69(70)$ & $53(54)$ & 63 \\
\hline $4 \mathrm{~h}$ & 107 & $79(80)$ & $78(80)$ & $71(73)$ & $67(71)$ & $50(53)$ & $58(60)$ \\
\hline $5 \mathrm{~h}$ & $106(107)$ & $72(73)$ & $73(75)$ & $67(70)$ & $62(73)$ & $47(53)$ & $54(58)$ \\
\hline FCCP & $241(244)$ & $95(96)$ & $120(124)$ & 162 (169) & $189(221)$ & $117(134)$ & $111(123)$ \\
\hline \multicolumn{8}{|c|}{ FURA PE3 $340 / 380 \mathrm{~nm}$ ratios } \\
\hline $25 \mathrm{~K} \mathrm{cntl}$ & 1.44 & 1.35 & 1.33 & 1.40 & 1.49 & 1.32 & 1.51 \\
\hline $1 \mathrm{~h}$ & 1.39 & 1.55 & 1.36 & 0.86 & 0.82 & 0.84 & 1.04 \\
\hline $2 \mathrm{~h}$ & 1.34 & 1.47 & 1.35 & 0.86 & 0.85 & 0.84 & 0.99 \\
\hline $3 h$ & 1.29 & 1.41 & 1.32 & 0.88 & 0.88 & 0.86 & 0.99 \\
\hline $4 \mathrm{~h}$ & 1.22 & 1.32 & 1.29 & 0.87 & 0.90 & 0.86 & 0.99 \\
\hline $5 \mathrm{~h}$ & 1.13 & 1.25 & 1.22 & 0.87 & 0.98 & 0.86 & 1.01 \\
\hline FCCP & 1.42 & 1.23 & 1.38 & 1.03 & 1.08 & 1.01 & 1.16 \\
\hline \multicolumn{8}{|c|}{ Morphology } \\
\hline $1 \mathrm{~h}$ & 0 & 0 & 1 & 0 & 0 & 0 & 0 \\
\hline $2 \mathrm{~h}$ & 0 & 0 & 3 & 2 & 0 & 1 & 0 \\
\hline $3 h$ & 0 & 1 & 3 & 3 & 2 & 2 & 3 \\
\hline $4 h$ & 0 & 1 & 5 & 3 & 14 & 11 & 15 \\
\hline $5 \mathrm{~h}$ & 0 & 2 & 8 & 4 & 31 & 17 & 24 \\
\hline \multicolumn{8}{|c|}{ Annexin $V$} \\
\hline $5 \mathrm{~h}$ & 3 & 4 & 9 & 13 & 40 & 33 & 28 \\
\hline
\end{tabular}

Experiments were conducted as described in Figure 1 except that perfusions with buffers differing in $\mathrm{K}^{+}$, serum, or Ca ${ }^{2+}$ were maintained for $5 \mathrm{~h}$. Respiration was normalized to the initial rate in standard $25 \mathrm{~K}$ media (25 K control). Buffers differing from the standard $25 \mathrm{~K}$ media were: $25 \mathrm{mM} \mathrm{KCl}, 0.4 \% \mathrm{BSA}, 100 \mathrm{mM} \mathrm{NaCl}(25 \mathrm{~K} /$ $\mathrm{BSA}), 25 \mathrm{mM} \mathrm{KCl}, 0.4 \% \mathrm{BSA}, 115 \mathrm{mM} \mathrm{NaCl}(25 \mathrm{~K} / \mathrm{BSA} / \mathrm{NaCl}), 25 \mathrm{mM} \mathrm{KCl}, 10 \%$ dialyzed $\mathrm{FBS}, 0.02 \mathrm{mM} \mathrm{CaCl}_{2}\left(25 \mathrm{~K} / 0.02 \mathrm{Ca}{ }^{2+}\right)$; the standard $3.5 \mathrm{~K} \mathrm{media}(3.5 \mathrm{~K})$; $10 \mathrm{mM} \mathrm{KCl}, 0.4 \% \mathrm{BSA}(10 \mathrm{~K})$; and $15 \mathrm{mM} \mathrm{KCl}, 0.4 \% \mathrm{BSA}(15 \mathrm{~K})$. Osmolarity was maintained by adjusting NaCl concentration appropriately. Numbers in parentheses are rates corrected for dead cells (see Materials and Methods). Protonophore (FCCP) addition at the end of the experiment was either $3 \mu \mathrm{M}$ (for $25 \mathrm{~K}$ and $25 \mathrm{~K} / 0.02$ $\mathrm{Ca}^{2+}$ ) or $9 \mu \mathrm{M}$ (for $25 \mathrm{~K} / \mathrm{BSA}, 25 \mathrm{~K} / \mathrm{BSA} / \mathrm{NaCl}, 3.5,10$, and $15 \mathrm{~K}$ ). Cytoplasmic $\mathrm{Ca}^{2+}$ levels are listed as FURA PE3 $340: 380 \mathrm{~nm}$ ratio. Values were averaged from at least 10 cells that showed no morphological signs of apoptosis during the experiment. During the experiments, apoptosis in the single fields that were imaged was estimated by changes in cell morphology (see Materials and Methods). At the end of each experiment, cells were stained with annexin $V$ and cells from at least four random fields were counted for positive staining (see Figure 10). Data are from single experiments

\section{$\mathrm{Ca}^{2+}$-dependent mechanisms contribute to the decreased ATP turnover in low $\mathrm{K}^{+}$}

Transfer to low $\mathrm{K}^{+}$causes a dramatic lowering of $\left[\mathrm{Ca}^{2+}\right]_{\mathrm{c}}$ that parallels changes in respiration (Figure 1). The possibility that $\left[\mathrm{Ca}^{2+}\right]_{\mathrm{c}}$ exerts control over cellular ATP demand under these conditions was tested by determining the relationship between respiration and $\left[\mathrm{Ca}^{2+}\right]_{c}$ as cells were equilibrated with a range of $\mathrm{K}^{+}$concentrations from 25 to $3.5 \mathrm{mM}$ (Figure 6a), and comparing this with an experiment in which $\left[\mathrm{Ca}^{2+}\right]_{\mathrm{c}}$ was altered by equilibrating cells in high $\mathrm{K}^{+}$with decreasing concentrations of external $\mathrm{Ca}^{2+}$. Over the range from 25 to $15 \mathrm{~mm} \mathrm{~K}^{+}$, the relationship between respiration and $\left[\mathrm{Ca}^{2+}\right]_{\mathrm{c}}$ monitored by FURA-PE3 could be superimposed on that obtained by decreasing external $\mathrm{Ca}^{2+}$ in high $\mathrm{K}^{+}$medium (Figure $6 b$ ), indicating that most, if not all, of the change in respiration on lowering $\mathrm{K}^{+}$was due to the change in $\left[\mathrm{Ca}^{2+}\right]_{\mathrm{C}}$. Furthermore, the decrease was due to a reduction in ATP turnover, as mitochondrial ATP synthesis was the only respiratory component reduced (by $30 \%$ ) on lowering external $\mathrm{Ca}^{2+}$ to $0.02 \mathrm{mM}$ (Figure $6 \mathrm{~d}$ ). When $\mathrm{K}^{+}$was reduced from 15 to $10 \mathrm{mM}$, there was a large decrease in respiration that was tetrodotoxin (TTX)-sensitive (see below), but further reduction in $\mathrm{K}^{+}$resulted in an increase, with no significant change in $\left[\mathrm{Ca}^{2+}\right]_{\mathrm{c}}$ (Figure 6a). Replacing $\mathrm{NaCl}$ with choline chloride eliminated the respiratory increase from 10 to $3.5 \mathrm{mM} \mathrm{KCl}$ (not shown), suggesting that this increase was due to the bioenergetic load of enhanced $\mathrm{Na}^{+}$influx as the plasma membrane hyperpolarized. These data indicate that $\mathrm{Na}^{+}$ cycling in $3.5 \mathrm{mM} \mathrm{K}^{+}$is nearly the same as in $25 \mathrm{mM} \mathrm{K}^{+}$, and the respiratory decrease in low $\mathrm{K}^{+}$is mostly due to the reduction in $\left[\mathrm{Ca}^{2+}\right]_{\mathrm{c}}$.

To investigate the contribution of $\mathrm{Na}^{+}$cycling, the $\mathrm{KCl}$ titration was repeated in the presence of $1 \mu \mathrm{M} \mathrm{TTX}$ to block at least some of the voltage-sensitive $\mathrm{Na}^{+}$channels (Figure 6c). TTX inhibited basal high $\mathrm{K}^{+}$respiration by $11 \%$, equivalent to a $15 \%$ reduction in ATP turnover after correcting for ATP. independent respiration. Thus it can be concluded that $\mathrm{Na}^{+}$ cycling through TTX-sensitive $\mathrm{Na}^{+}$channels accounts for $15 \%$ of mitochondrial ATP synthesis in high $\mathrm{K}^{+}$. The TTXsensitive component remained the same down to $15 \mathrm{mM} \mathrm{K}^{+}$, but was completely abolished at $10 \mathrm{mM} \mathrm{K}^{+}$, indicating that TTX-sensitive $\mathrm{Na}^{+}$channels were no longer flickering at this plasma membrane potential $\left(\Delta \psi_{p}\right)$. Closure of these channels therefore accounts for the steep drop in respiration from 15 to $10 \mathrm{mM} \mathrm{KCl}$, and is consistent with the ineffectiveness of the open-channel inhibitor veratridine in low $\mathrm{K}^{+}$media (Figure 4). Surprisingly, as cells transitioned from 10 to $3.5 \mathrm{mM} \mathrm{KCl,} \mathrm{TTX}$ did not block the respiratory increase, but to the contrary, further stimulated it (Figure 6C). There are reports of TTXinsensitive $\mathrm{Na}^{+}$channels in dorsal root ganglion neurons ${ }^{17}$ and myelinated axons of the optic nerve, ${ }^{18}$ raising the possibility that such channels are also present in CGNs. Thus, $\mathrm{Na}^{+}$influx through TTX-insensitive channels may be responsible for the respiratory rate increase at 5 and $3.5 \mathrm{mM}$ 


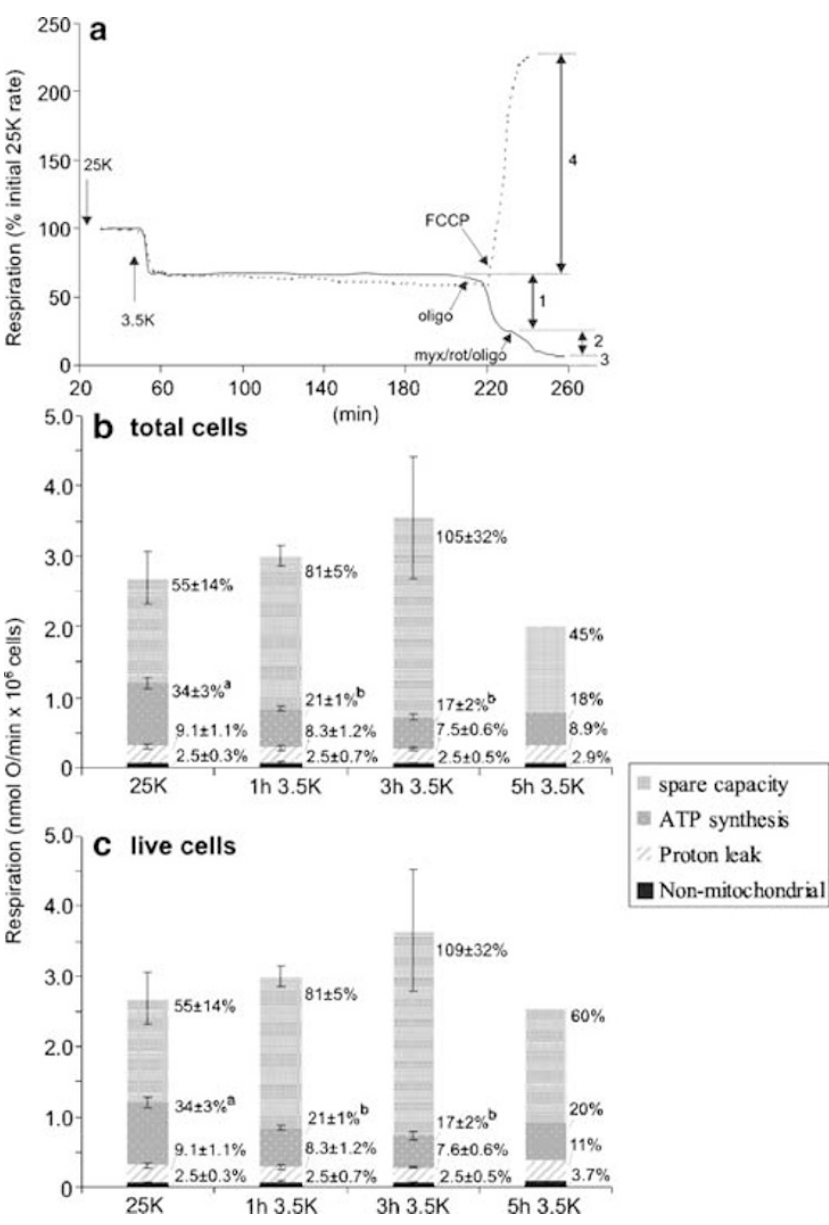

Figure 3 Mitochondrial ATP synthesis is reduced in low $\mathrm{K}^{+}$. Experiments were performed as described in Figure 1. (a) Superimposed traces are shown to illustrate the procedure used for determining mitochondrial ATP synthesis (1, decrease in rate with $0.2 \mu \mathrm{g} / \mathrm{ml}$ oligomycin (oligo)); mitochondrial $\mathrm{H}^{+}$leak (2, further decrease in rate with $2 \mu \mathrm{M}$ myxothiazol, $1 \mu \mathrm{M}$ rotenone, and $0.2 \mu \mathrm{g} / \mathrm{ml}$ oligomycin (myx/rot/oligo)); non-mitochondrial respiration (3, residual rate) and spare respiratory chain capacity (4, increase in respiration on adding $9 \mu \mathrm{M}$ FCCP). Experiments with cells maintained in the standard high $\mathrm{K}^{+}$media were performed in parallel, but all additions were in one experiment. The data summarized in (b), are expressed as mean + S.E.M. for $25 \mathrm{~K}, 1 \mathrm{~h} 3.5 \mathrm{~K}$, and $3 \mathrm{~h}$ $3.5 \mathrm{~K}$ experiments $(n=3)$, or as values from a single experiment $(5 \mathrm{~h} 3.5 \mathrm{~K})$. The sum of respiration components in $25 \mathrm{~K}$ was taken as $100 \%$. The data in (c) were corrected for dead cells (see Materials and Methods), which became prominent after $5 \mathrm{~h}$ in $3.5 \mathrm{~K}$. Numbers sharing common superscripts or having no superscripts are not significantly different by one-way ANOVA with Tukey's post hoc test

$\mathrm{K}^{+}$. However, it is unclear why TTX stimulates respiration at 5 and $3.5 \mathrm{mM} \mathrm{K}^{+}$above that seen without TTX.

\section{Steady-state superoxide levels increase in a low $\mathrm{K}^{+}$media}

Oxidative stress is implicated as an early event in low $\mathrm{K}^{+}$-induced apoptosis. ${ }^{19} \mathrm{In}$ isolated mitochondria, $\mathrm{O}_{2}^{-}$production is very sensitive to changes in $\Delta p^{20-22}$ In CGNs incubated in low $\mathrm{K}^{+}$media, the in situ mitochondria are closer to respiratory state 4 , and it would be predicted that $\Delta p$, and hence ROS production, could be enhanced. It should be noted that comparison of fluorescence signals from cationic 'mitochondrial' membrane potential indicators cannot be used to quantify the difference in $\Delta \psi_{\mathrm{m}}$ on switching to low $\mathrm{K}^{+}$due to the large effect of the altered $\Delta \psi_{\mathrm{p}}$ on the probe distribution. To determine if steady-state cell $\mathrm{O}_{2}^{-}$levels differ between high and low $\mathrm{K}^{+}$, and if such a difference could be due to changes in mitochondrial respiration, cells were perfused in buffers supplemented with $0.2 \mu \mathrm{M}$ dihydroethidium (DHE) (Figure 7). From high to low $\mathrm{K}^{+}$, respiration declined and $\mathrm{DHE}$ oxidation rate increased by $51 \%$ (Figure $7 \mathrm{a}$ ). However, this increase was not mediated by an approach to state 4 , since addition of sufficient protonophore ( $1 \mu \mathrm{M} \mathrm{FCCP})$ to restore the initial respiratory rate seen in high $\mathrm{K}^{+}$did not reverse the increase. It is important to note that $1 \mu \mathrm{M}$ FCCP did not affect the FURA PE3 ratio (not shown, but see Figure 11)

As a further test, the perfusion order was reversed (Figure 7b). Consistent with the first experiment, DHE oxidation rate decreased significantly $(52 \%)$ from low to high $\mathrm{K}^{+}$. This was followed by perfusion in high $\mathrm{K}^{+}$with $0.02 \mathrm{mM}$ $\mathrm{Ca}^{2+}$ to reduce respiration close to the initial low $\mathrm{K}^{+}$rate by decreasing $\left[\mathrm{Ca}^{2+}\right]_{\mathrm{c}}$ (not shown, but see Figure 6 ). This buffer returned $\mathrm{DHE}$ oxidation rate back to the initial low $\mathrm{K}^{+}$rate. In a third set of experiments (Figure 7c), DHE oxidation rate increased (58\%) from upon transfer from high to low $\mathrm{K}^{+}$. Respiratory rate was restored to the high $\mathrm{K}^{+}$condition by the addition of $14 \mathrm{nM}$ BTx to the low $\mathrm{K}^{+}$media to stimulate ATP turnover. Consistent with Expt. $7 \mathrm{~A}$, increasing respiration back to the high $\mathrm{K}^{+}$rate did not reverse the increased DHE oxidation rate.

The combined data from these experiments show that steady-state cell $\mathrm{O}_{2}^{-}$levels are significantly elevated in low $\mathrm{K}^{+}$ (Figure 7f), and that this variable significantly correlates with changes in $\left[\mathrm{Ca}^{2+}\right]_{\mathrm{c}}$ (Figure 7e) but not with mitochondrial respiration (Figure $7 \mathrm{~d}$ ) (and by extension, with $\Delta p$ ).

To determine if low $\mathrm{K}^{+}$-induced changes in steady-state $\mathrm{O}_{2}^{-}$, mitochondrial respiration, or $\left[\mathrm{Ca}^{2+}\right]_{\mathrm{c}}$ are unique to $\mathrm{CGNs}$, one set of experiments was repeated using hippocampal neurons that do not undergo apoptosis in low $\mathrm{K}^{+}$(Figure 8). Similar to CGNs, hippocampal neuron respiration increased from low to high $\mathrm{K}^{+}$, but the response was significantly lower than with CGNs $(1.32 \pm 0.05$ versus $1.52 \pm 0.04-$ fold increase, resp.; $P=0.03$ ) (Figure $8 \mathrm{a}$ ). The respiratory response to $0.02 \mathrm{mM}$ external $\mathrm{Ca}^{2+}$ was also significantly lower than with CGNs $(P=0.002)$. Cytoplasmic $\mathrm{Ca}^{2+}$ varied with $\mathrm{KCl}$ and external $\mathrm{Ca}^{2+}$ (Figure $8 \mathrm{~b}$ ). These qualitatively similar responses were not reflected with similar changes in DHE oxidation rate (Figure $8 \mathrm{c}$ ). Consequently, there was no correlation between $\left[\mathrm{Ca}^{2+}\right]_{\mathrm{c}}$ and steady-state $\mathrm{O}_{2}^{-}$levels in hippocampal neurons (Figure 8d).

\section{Relationships between bioenergetic parameters and apoptotic morphology}

Since this study focuses on the first $3-5 \mathrm{~h}$ of low $\mathrm{K}^{+}$exposure it is relevant to establish the extent to which recognized morphological correlates of apoptosis occur during this period. This is particularly important in the present context, where the respirometer of necessity monitors the average population respiration. An early event is the loss of plasma 

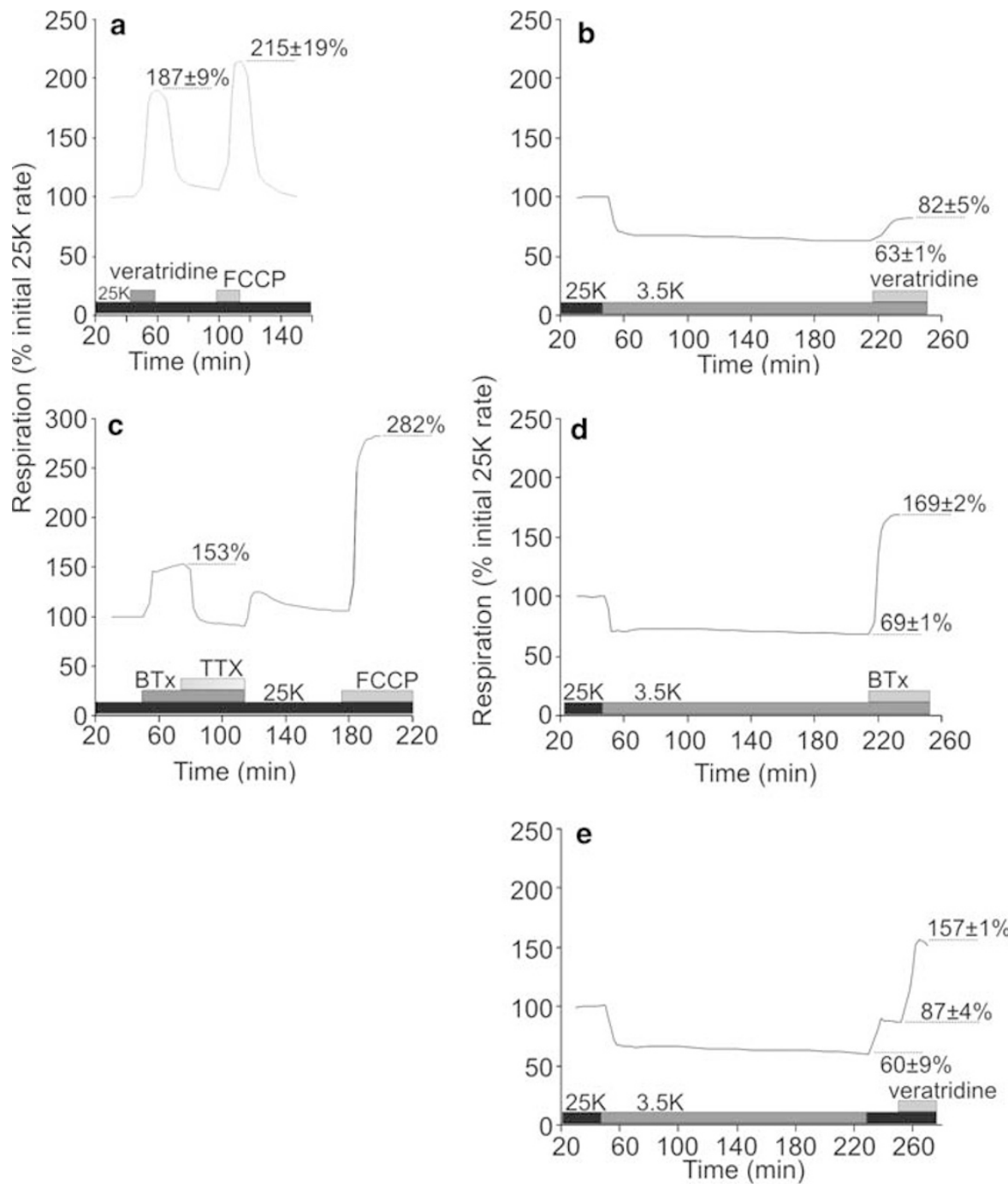

Figure 4 CGNs respond to increased cellular ATP demand in both high and low $\mathrm{K}^{+}$. Experiments were performed as described in Figure 1. (a) In high $\mathrm{K}^{+}$media $(25 \mathrm{~K}), 2 \mu \mathrm{M}$ veratridine increased plasma membrane $\mathrm{Na}^{+}$cycling, and thus ATP turnover, sufficiently to utilize most of the spare capacity of the respiratory chain, assessed using $3 \mu \mathrm{M}$ FCCP. (b) Veratridine is ineffective in low $\mathrm{K}^{+}$medium due to its voltage-dependency. (c, d) BTx (100 nM) increased $\mathrm{Na}^{+}$cycling in both high and low $\mathrm{K}^{+}$media. The effect of TTX $(1 \mu \mathrm{M})$ confirmed that respiration increased due to opening of $\mathrm{Na}^{+}$channels. (e) When cells were returned to high $\mathrm{K}^{+}$after $3 \mathrm{~h}$ perfusion with standard low $\mathrm{K}^{+}$media, $2 \mu \mathrm{M}$ veratridine stimulated respiration to a similar extent as BTx. Data are mean \pm S.D. of two independent experiments except for (c) which was a single experiment. Initial basal $25 \mathrm{~K}$ respiration (nmol O/min $\times 10^{6}$ cells) were (a) $1.09 \pm 0.27$, (b) $0.80 \pm 0.26$, (c) 1.52 , (d) $1.38 \pm 0.02$, and (e) $1.03 \pm 0.28$

membrane phospholipid polarity, seen as externalization of phosphatidylserine detected by annexin $\mathrm{V}$ staining. ${ }^{23}$ By $3 \mathrm{~h}$ in low $\mathrm{K}^{+} 13 \%$ of CGNs showed annexin binding, while at the same time the later stage of nuclear condensation revealed by SYTO13 nuclear staining could be detected in $3 \%$ of cells (Figure 9).

Because of the increased steady-state $\mathrm{O}_{2}^{-}$levels generated in low $\mathrm{K}^{+}$medium (Figure 7), it was of interest to determine if higher DHE oxidation rates were associated with the development of apoptosis. For this, CGNs were perfused $1 \mathrm{~h}$ in the standard low $\mathrm{K}^{+}$media, followed by perfusion with low $\mathrm{K}^{+}$ media plus $0.2 \mu \mathrm{M}$ DHE for $3 \mathrm{~h}$. DHE oxidation rates of individual cells were followed over this time, and after $4 \mathrm{~h}$ total low $\mathrm{K}^{+}$, cells were stained with annexin V (Figure 10). There was no significant difference in DHE oxidation rate between non-staining cells and cells staining positive for annexin $\mathrm{V}$.
To determine if lowered mitochondrial respiration in low $\mathrm{K}^{+}$ is important in apoptosis, CGNs were switched from standard high $\mathrm{K}^{+}$media to low $\mathrm{K}^{+}$plus $1 \mu \mathrm{M} \mathrm{FCCP}$ for $4 \mathrm{~h}$ (Figure 11). Using these conditions, respiration was maintained very close to the basal high $\mathrm{K}^{+}$rate throughout the $4 \mathrm{~h}$ perfusion (Figure $11 \mathrm{a})$, and $\left[\mathrm{Ca}^{2+}\right]_{\mathrm{c}}$ was no different than with the standard low $\mathrm{K}^{+}$media (Figure 11b). After $4 \mathrm{~h}$, the percentage apoptosis by SYTO13 staining was not significantly different from the standard low $\mathrm{K}^{+}$media (Figure 11c). In contrast, annexin $\mathrm{V}$ staining was significantly reduced by FCCP treatment.

To further test the relationship between mitochondrial respiration and apoptosis progression, cells were perfused for $5 \mathrm{~h}$ with buffers varying in either serum, $\mathrm{KCl}$ or $\mathrm{CaCl}_{2}$, monitored for morphological signs of apoptosis, and subsequently stained with annexin $\mathrm{V}$ (Table 1). Interestingly, serum deprivation alone had little effect on promoting apoptosis but 


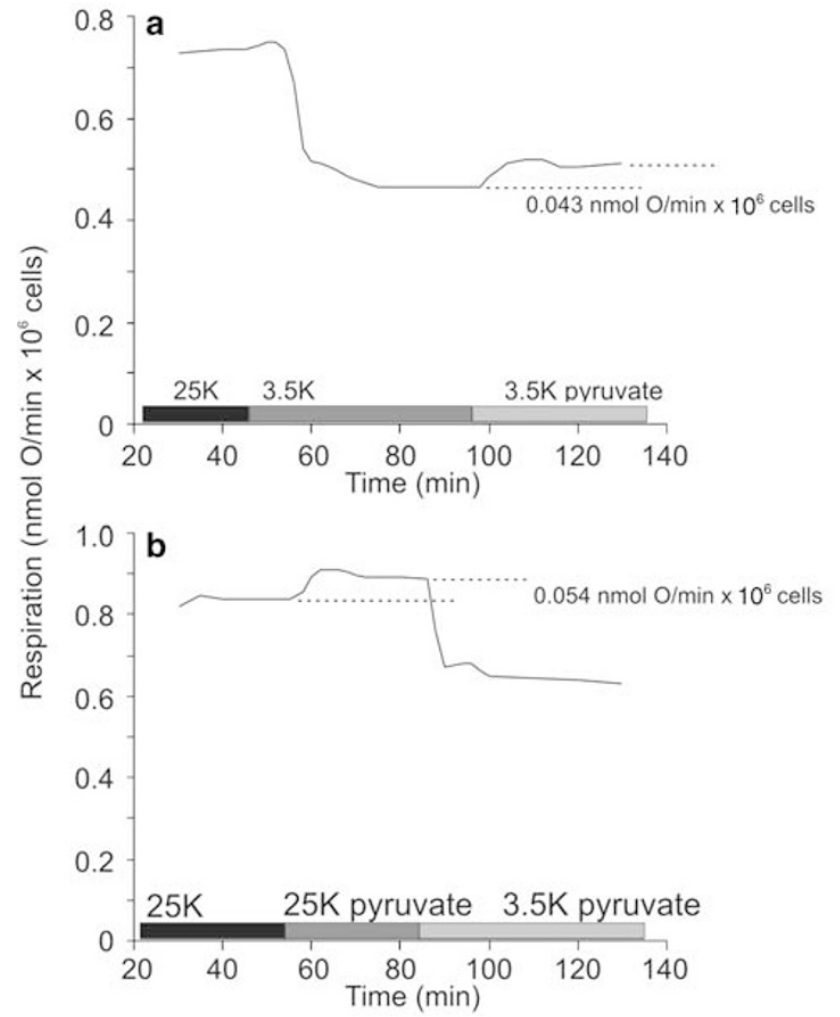

Figure 5 Glycolytic ATP synthesis in high and low $\mathrm{K}^{+}$media. Experiments were performed as described in Figure 1. The effects of low $\mathrm{K}^{+}(\mathbf{a})$ and high $\mathrm{K}^{+}$ (b) on glycolytic ATP synthesis rate was determined by replacing $15 \mathrm{mM}$ glucose with $10 \mathrm{mM} \mathrm{Na}^{+}$pyruvate. The increase in respiration, as indicated, reflects glycolytic ATP synthesis rate. Data are from single experiments

substantially impaired protonphore-stimulated respiration. In high $\mathrm{K}^{+}$with $0.02 \mathrm{mM} \mathrm{Ca}^{2+}$, respiration was reduced close to the low $\mathrm{K}^{+}$rate, yet the percentage apoptotic cells after $5 \mathrm{~h}$ was far less than in low $\mathrm{K}^{+}$. A similar trend was seen with cells in $15 \mathrm{mM} \mathrm{KCl}$, respiration was reduced to the same extent as in low $\mathrm{K}^{+}$, but the number of apoptotic cells was reduced. Cells in $10 \mathrm{mM} \mathrm{KCl}$ exhibited the greatest reduction in respiration (Table 1 and Figure 6) but also displayed a slightly lower number of apoptotic cells compared to $3.5 \mathrm{mM} \mathrm{K}^{+}$. Taken together, neither lower mitochondrial respiration nor lower $\left[\mathrm{Ca}^{2+}\right]_{c}$ per se seem sufficient to account for CGN apoptosis occurring during the first $5 \mathrm{~h}$ of exposure to low $\mathrm{K}^{+}$medium.

Figure 12 shows typical whole-cell $\mathrm{TMRM}^{+}$and FURA PE3 fluorescence of apoptotic and nonapoptotic cells over the $5 \mathrm{~h}$ perfusions. In nonquench mode, increased whole-cell $\mathrm{TMRM}^{+}$fluorescence indicates greater probe accumulation due to hyperpolarization of the plasma and/or mitochondrial inner membrane. Cells maintained in high $\mathrm{K}^{+}$showed little change in $\mathrm{TMRM}^{+}$fluorescence irrespective of the presence of serum (Figure 12a and b) while those exposed to low $\mathrm{K}^{+}$ typically showed a 4-6-fold increase (Figure 12c and $\mathrm{d}-\mathrm{f}$ ) primarily due to plasma membrane hyperpolarization. Cells undergoing apoptosis in $3.5 \mathrm{~K} / \mathrm{BSA}$ typically lost their accumulated $\mathrm{TMRM}^{+}$before showing morphological signs of apoptosis (Figure 12d-f). Importantly, FCCP and oligomycin addition to apoptotic cells elicited increases in $\left[\mathrm{Ca}^{2+}\right]_{\mathrm{c}}$ as shown by the FURA PE3 340/380 increase.

\section{Discussion}

Low $\mathrm{K}^{+}$exposure of CGNs initiates a complex set of proapoptotic, metabolic, and signal transduction mechanisms that include Fas receptor activation, ${ }^{24}$ upregulation of $\mathrm{c}$-jun target genes, ${ }^{25}$ translocation of Bax to the mitochondrion, ${ }^{26,27}$ cytochrome $c$ release, ${ }^{5,28}$ and caspase 3 activation. $^{29}$ The bioenergetic effects of low $\mathrm{K}^{+}$that have been reported include an extensive inhibition of glycolysis, ${ }^{7}$ increased levels of reactive oxygen species, ${ }^{19}$ and mitochondrial dysfunction. ${ }^{4,30}$

Until recently, the only way to monitor the respiration of cultured neurons has involved the trauma of cell suspension or homogenization. However, the development of the cell respirometer $^{9}$ has allowed the in situ bioenergetics of neuronal mitochondria to be reinvestigated with much greater precision, and in particular to assess critically the proposal that impairment of cellular respiration is an early and crucial step in the cell death program. ${ }^{4}$ While one of the main findings of this study is that CGNs exhibit an immediate reduction in mitochondrial respiration upon $\mathrm{K}^{+}$/serum deprivation (Figures 1 and 2), this is not a consequence of mitochondrial dysfunction, but is rather a consequence of decreased ATP turnover within the cell (Figures 3 and 5). The decrease in ATP turnover correlates with the decreased $\left[\mathrm{Ca}^{2+}\right]_{c}$, although the locus of the $\mathrm{Ca}^{2+}$-sensitive ATP consuming reaction was not established in this study. These results are consistent with recent experiments showing that the ATP:ADP ratio increases in CGNs exposed to low $\mathrm{K}^{+},{ }^{31}$ but the respirometer allows us to eliminate other explanations for the decreased respiration, such as impaired ATP/ADP exchange (Figure 4), respiratory chain inhibition (Figure 2), or inhibition of substrate supply to the mitochondria (Figure 2). This approach to state 4 respiration is accompanied by reduced glycolysis (Figure 5) and is thus not due to a switch from oxidative to glycolytic ATP production.

The progression of apoptosis with little change in viable cell respiration (Table 1) indicates that mitochondrial dysfunction is not an early event in this process. Individual cells were imaged for $\left[\mathrm{Ca}^{2+}\right]_{c}$ and $\mathrm{TMRM}^{+}$to further assess this possibility. Cells started to lose their accumulated TMRM $^{+}$ about $1 \mathrm{~h}$ before acquiring morphological features characteristic of apoptosis (Figure 12d-f), indicating depolarization of the plasma membrane, mitochondrial inner membrane, or both. Calcium homeostasis was largely maintained until the morphological stage was apparent (Figure 12d) or until addition of protonophore (Figure 12e) or oligomycin (Figure 12f). This is consistent with maintained mitochondrial function (see also Table 1) and therefore indicates that the $\mathrm{TMRM}^{+}$loss may be ascribed to a partial plasma membrane depolarization. The variable extent to which $\left[\mathrm{Ca}^{2+}\right]_{\mathrm{c}}$ homeostasis is maintained during plasma membrane depolarization (Figure 12d-f) could possibly reflect inactivation of voltagesensitive $\mathrm{Ca}^{2+}$ channels, perhaps by proteolysis.

There is extensive evidence that oxidative stress is a component in low- $\mathrm{K}^{+}$apoptosis of CGNs. ${ }^{19,32-34}$ One 
a

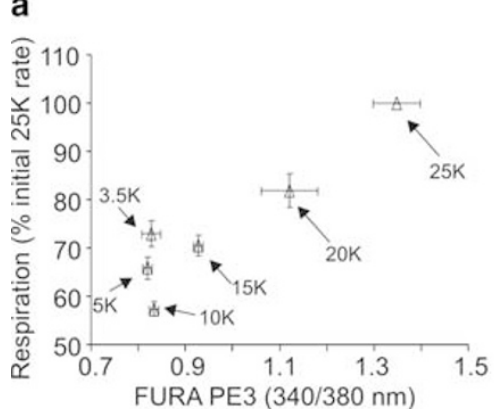

b

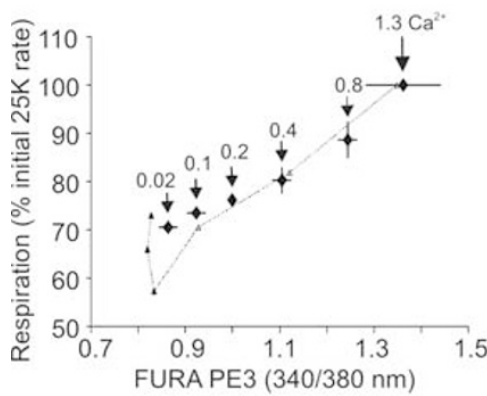

C

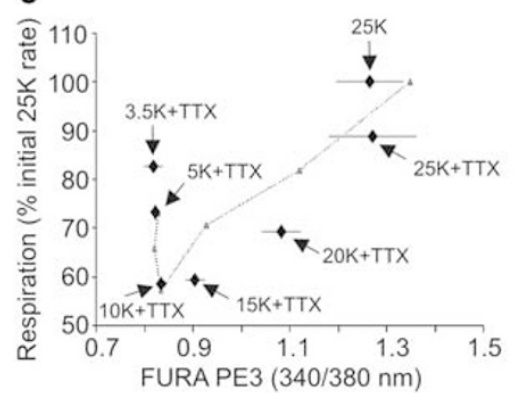

d

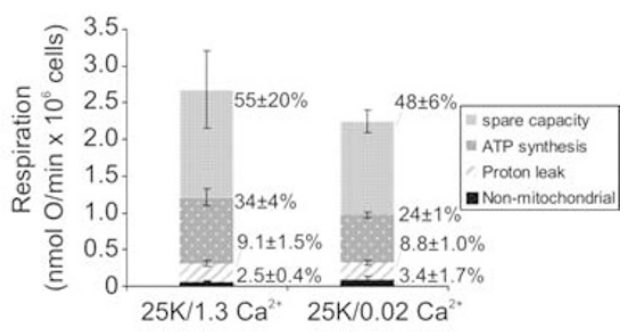

Figure 6 Reduced respiration in low $\mathrm{K}^{+}$is primarily due to lower cytoplasmic $\mathrm{Ca}^{2+}$. (a) Cells were perfused sequentially with serum-containing buffers differing in $\mathrm{KCl}$ concentration (indicated, in mM). NaCl was adjusted appropriately. Respiration and FURA PE3 $340: 380 \mathrm{~nm}$ ratios (average of 20 cells) were correlated. (b) Cells were perfused sequentially with $25 \mathrm{mM} \mathrm{KCl} / 10 \%$ serum buffers differing in $\mathrm{Ca}^{2+}$ concentration (indicated, in $\mathrm{mM}$ ). Diamonds show the $\mathrm{Ca}^{2+}$ titration, with the $\mathrm{KCl}$ titration from (a) (line) superimposed for comparison. (c) The $\mathrm{KCl}$ titration was repeated with $1 \mu \mathrm{M} \mathrm{TTX}$ to determine the contribution of $\mathrm{Na}^{+}$cycling; the $\mathrm{KCl}$ (-TTX) titration from (a) (line) is superimposed for comparison. (d) Respiration components determined for cells in high $\mathrm{K}^{+}$, low $\mathrm{Ca}^{2+}$ media $\left(25 \mathrm{~K}^{2} 0.02 \mathrm{Ca}^{2+}\right)$. Experiments were performed as described in Figure 3 and reference data for cells in standard high $\mathrm{K}^{+}$media $\left(25 \mathrm{~K} / 1.3 \mathrm{Ca}^{2+}\right)$ were taken from Figure 3 for comparison. Percentages are based on the sum of respiration components for $25 \mathrm{~K} / 1.3 \mathrm{Ca}^{2+}$ as previously described. Data are mean \pm S.E.M. of 3-4 independent experiments (a-c) or mean \pm S.D. of two independent experiments (d)

predicted consequence of reduced ATP turnover, without direct inhibition of either substrate supply or the respiratory chain, is an increased $\Delta \psi_{\mathrm{m}}$ (or more strictly protonmotive force, $\Delta p$ ). Studies with isolated mitochondria have shown that $\mathrm{O}_{2}^{-}$production increases exponentially at high $\Delta p$ as mitochondria approach state $4,^{20-22,35}$ and this could explain why CGNs exhibit increased $\mathrm{O}_{2}^{-}$levels in low $\mathrm{K}^{+}$. Mechanistically this is important since some studies have suggested that increased $\mathrm{O}_{2}^{-}$production may serve as a signaling pathway initiating apoptosis. ${ }^{4,29,36,37}$ In the current experiments, steady-state $\mathrm{O}_{2}^{-}$levels in low $\mathrm{K}^{+}$were significantly greater than in high $\mathrm{K}^{+}$(Figure $7 \mathrm{f}$ ), consistent with this possibility. However, mitochondrial respiration (and hence presumably $\Delta p$ ) did not show a significant correlation with steady-state cell $\mathrm{O}_{2}^{-}$levels (Figure $7 \mathrm{~d}$ ).

Most experiments demonstrating a $\mathrm{O}_{2}^{-} / \Delta p$ relationship with isolated mitochondria have used succinate as a nonphysiological substrate, ${ }^{20,22,38}$ since flavoprotein-linked dehydrogenases can generate supra-maximal protonmotive forces. ${ }^{39}$ While this could potentially account for the discrepancy between isolated and in situ mitochondria, other studies have shown that isolated brain mitochondria oxidizing more physiological complex I substrates also exhibit a steep $\mathrm{O}_{2}^{-} / \Delta p$ relationship. ${ }^{21,35}$ This could either indicate that the $\mathrm{O}_{2}^{-} / \Delta p$ relationship seen in isolated mitochondria is not valid for mitochondria within these cells, or that the changes in mitochondrial $\mathrm{O}_{2}^{-}$production are too small to be detected by DHE oxidation.

If the changes in mitochondrial $\mathrm{O}_{2}^{-}$production are too small to detect with DHE, the possibility remains that approach to state 4 and the associated increased oxidative stress are important for signaling apoptosis in low $\mathrm{K}^{+}$. However, the $\mathrm{KCl}$ titrations show that mitochondrial respiration is most depressed in $10 \mathrm{mM} \mathrm{K}^{+}$(Figure 6a and Table 1), and depressed to the same extent in 15 and $3.5 \mathrm{mM} \mathrm{K}^{+}$, whereas apoptosis progression over $5 \mathrm{~h}$ is greatest in $3.5 \mathrm{mM} \mathrm{K}^{+}$(Table 1). Additionally, maintaining mitochondrial respiration at the high $\mathrm{K}^{+}$rate over $4 \mathrm{~h}$ in low $\mathrm{K}^{+}$by titration with protonophore does not convincingly prevent apoptosis (Figure 11); the opposing results with STYO13 and annexin staining in this experiment could indicate that low FCCP concentrations impair phosphatidylserine externalization without preventing apoptosis. These data indicate that (1) approach to state 4 respiration is not necessary for apoptosis progression, and (2) if oxidative stress is an important signal, it may be from a source other than mitochondria.

In contrast to the lack of correlation with respiratory rate, DHE oxidation shows a significant negative correlation with $\left[\mathrm{Ca}^{2+}\right]_{\mathrm{c}}$ from high to low $\mathrm{K}^{+}$(Figure 7e). The FURA-PE3 ratio was not calibrated in this study, but from previous experiments, ${ }^{40-42}\left[\mathrm{Ca}^{2+}\right]_{\mathrm{c}}$ is about $40-50 \mathrm{nM}$ in low $\mathrm{K}^{+}$and 100-125 nM in high $\mathrm{K}^{+}$medium. Steady-state cell $\mathrm{O}_{2}^{-}$levels 
a
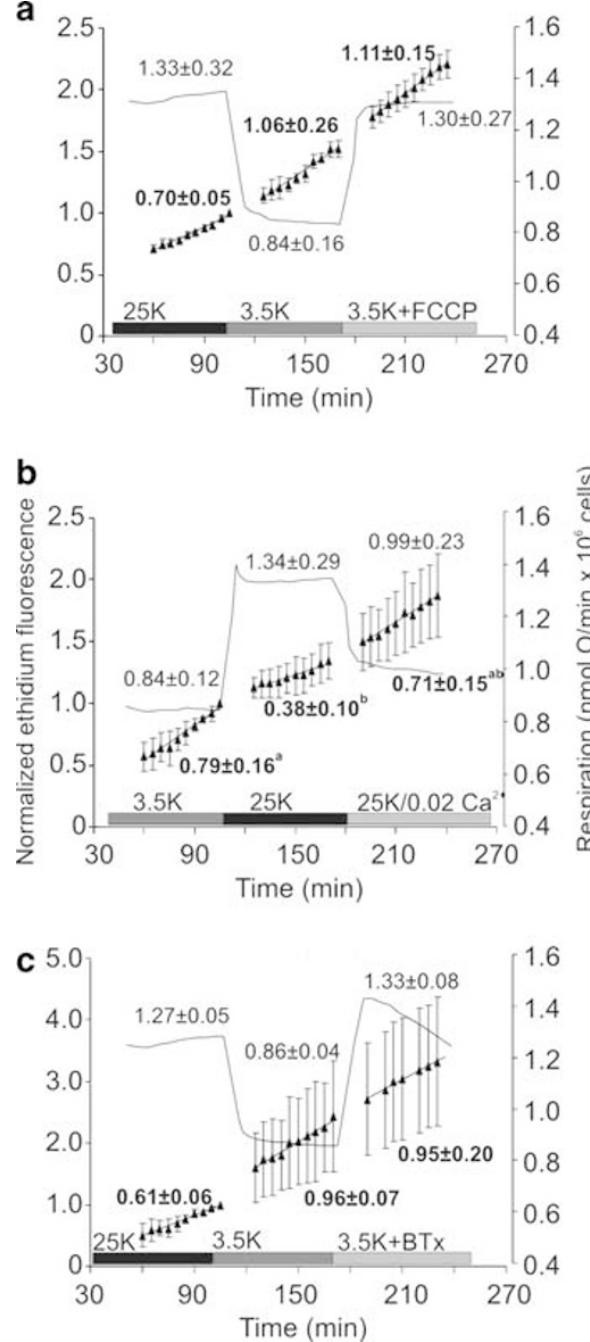

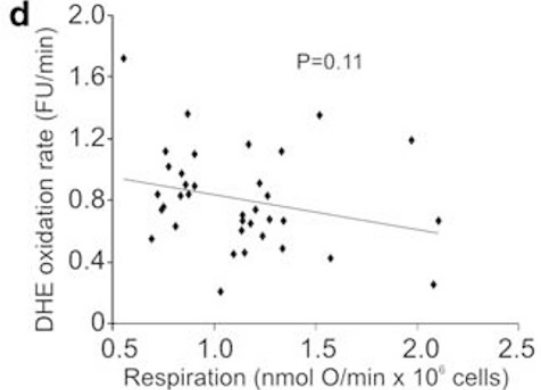

e
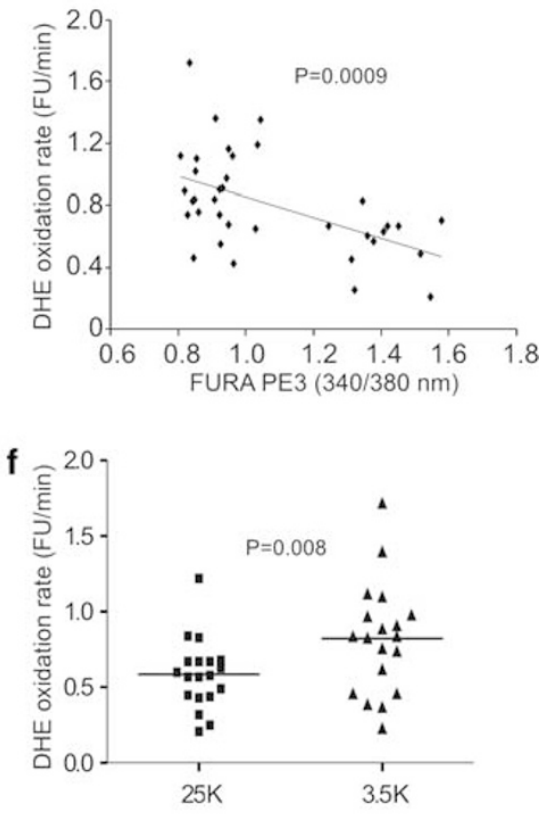

Figure 7 Superoxide levels vary with cytoplasmic $\mathrm{Ca}^{2+}$ but not with respiration rate. (a) Cells were preloaded with FURA PE3 AM. $0.2 \mu \mathrm{M}$ DHE was added to each buffer before initiating sequential perfusion with high $\mathrm{K}^{+}$buffer $(25 \mathrm{~K})$, low $\mathrm{K}^{+}$buffer $(3.5 \mathrm{~K})$, and low $\mathrm{K}^{+}$buffer with $1 \mu \mathrm{M}$ FCCP $(3.5 \mathrm{~K}+\mathrm{FCCP})$. Respiration (continuous trace) and ethidium fluorescence (triangles) were monitored. DHE oxidation rates (least-squares linear regression in FU/min) are in bold type, and respiration rates ( $\mathrm{nmol} \mathrm{O/min} \times 10^{6}$ cells) are in normal type. (b) Cells were perfused with low $\mathrm{K}^{+}$buffer $(3.5 \mathrm{~K})$, high $\mathrm{K}^{+}$buffer $(25 \mathrm{~K})$, and high $\mathrm{K}^{+}$buffer with $0.02 \mathrm{mM} \mathrm{CaCl}_{2}$ $\left(25 \mathrm{~K} / 0.02 \mathrm{Ca}^{2+}\right)$. (c) Cells were perfused with high $\mathrm{K}^{+}$buffer $(25 \mathrm{~K})$, low $\mathrm{K}^{+}$buffer $(3.5 \mathrm{~K})$, and low $\mathrm{K}^{+}$buffer with $14 \mathrm{nM} \mathrm{BTx}(3.5 \mathrm{~K}+\mathrm{BTx})$. (d) DHE oxidation rate for each condition in (a-c) was plotted as a function of the corresponding respiration rate. (e) DHE oxidation rate for each condition in (a-c) was plotted as a function of the average FURA PE3 $340: 380 \mathrm{~nm}$ ratio, determined from analysis of 20 cells in each experiment. (f) DHE oxidation rates from experiments in (a-c) are listed for high and low $\mathrm{K}^{+}$buffers. Statistics: repeated measures one-way ANOVA for DHE oxidation rate indicated no significant treatment effect $(P=0.15,0.14)$ for experiments $(\mathbf{a}$ and c) but significance $(P=0.02)$ for experiment (b), values sharing common superscripts are not different. The least-squares linear regression in (e) was significantly nonzero, as indicated, and by paired $t$-test, the mean rate in (f) was significantly greater in low $\mathrm{K}^{+}$versus high $\mathrm{K}^{+}$

may thus be regulated by $\left[\mathrm{Ca}^{2+}\right]_{c}$ within this range, by affecting either $\mathrm{O}_{2}^{-}$production or removal. Even in high $\mathrm{K}^{+}$ media, $\left[\mathrm{Ca}^{2+}\right]_{\mathrm{c}}$ in these cells is well below the 'set-point' at which mitochondria become significant net accumulators of $\mathrm{Ca}^{2+} \cdot{ }^{43}$ Therefore, it is possible that the $\mathrm{Ca}^{2+}$-sensitive $\mathrm{O}_{2}^{-}$production has a non-mitochondrial origin. If $\left[\mathrm{Ca}^{2+}\right]_{\mathrm{c}}$ regulates $\mathrm{O}_{2}^{-}$levels in CGNs, then hippocampal neurons, which exhibit $\left[\mathrm{Ca}^{2+}\right]_{\mathrm{c}}$ but not $\mathrm{O}_{2}^{-}$changes, could be lacking a $\mathrm{Ca}^{2+}$ sensor that affects $\mathrm{O}_{2}^{-}$production or scavenging. Alternatively, the similar $\left[\mathrm{Ca}^{2+}\right]_{\mathrm{c}}$ changes in both neuron types may suggest that the $\mathrm{O}_{2}^{-}$change in $\mathrm{CGNs}$ is unrelated to $\left[\mathrm{Ca}^{2+}\right]_{\mathrm{c}}$. Irrespective of the mechanism, enhanced $\mathrm{O}_{2}^{-}$in low $\mathrm{K}^{+}$could potentially serve either a permissive or primary role in signaling apoptosis. The fact that $\mathrm{O}_{2}^{-}$levels did not change in hippocampal neurons, which do not undergo low $\mathrm{K}^{+}$ apoptosis, is consistent with these possibilities (Figure 8).

If $\mathrm{O}_{2}^{-}$plays a primary role in CGNs, individual cells with higher $\mathrm{O}_{2}^{-}$levels would be predicted to undergo apoptosis more rapidly. However, cells undergoing apoptosis (assessed by annexin staining) after $4 \mathrm{~h}$ in low $\mathrm{K}^{+}$exhibited the same $\mathrm{O}_{2}^{-}$ levels as cells showing no signs of apoptosis (Figure 10). This indicates that quantitative differences in steady-state cellular $\mathrm{O}_{2}^{-}$levels are not important for apoptosis development, and therefore does not support a possible primary role for $\mathrm{O}_{2}^{-}$in signaling apoptosis.

Decreasing the external $\mathrm{Ca}^{2+}$ concentration to $0.02 \mathrm{mM}$ in high $\mathrm{K}^{+}$medium reduces $\left[\mathrm{Ca}^{2+}\right]_{\mathrm{c}}$ to the same extent as exposure of cells to low $\mathrm{K}^{+}$in the presence of $1.3 \mathrm{mM} \mathrm{Ca}^{2+}$ 

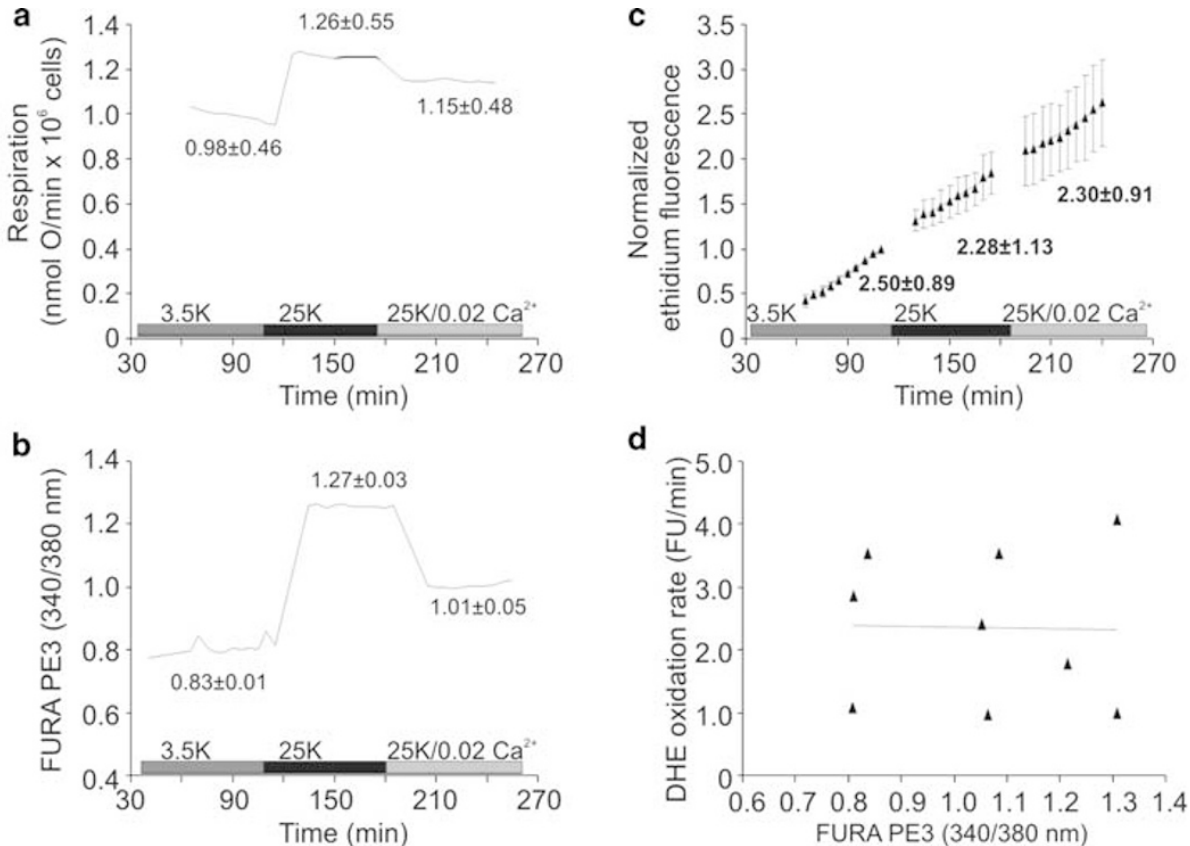

Figure 8 Hippocampal neurons respond to changes in external $\mathrm{K}^{+}$, but steady-state superoxide levels do not vary with cytoplasmic $\mathrm{Ca}^{2+}$. Experiments were performed as described in Figure 7, except that 1.3-2.0 $\times 10^{6}$ hippocampal neurons were used at 11 DIV. Here, the variables measured are plotted individually. Cells were sequentially perfused with low $\mathrm{K}^{+}$buffer $(3.5 \mathrm{~K})$, high $\mathrm{K}^{+}$buffer $(25 \mathrm{~K})$, and high $\mathrm{K}^{+}$buffer with $0.02 \mathrm{mM} \mathrm{CaCl}_{2}\left(25 \mathrm{~K}^{\prime} 0.02 \mathrm{Ca}^{2+}\right)$ as indicated. Cell respiration (a) and cytoplasmic $\mathrm{Ca}^{2+}$ (b) vary in a qualitatively similar manner to CGNs as external $\mathrm{K}^{+}$and $\mathrm{Ca}^{2+}$ change. DHE oxidation rate, determined by linear regression, did not change from low $\mathrm{K}^{+}$to high $\mathrm{K}^{+}$, or to high $\mathrm{K}^{+}$with low $\mathrm{Ca}^{2+}(P=0.78$, one-way repeated measures ANOVA) (c); consequently, there was no correlation between between DHE oxidation rate and cytoplasmic $\mathrm{Ca}^{2+}$ (d). Data are mean \pm S.E.M. of three independent experiments

(Figure 6 and Table 1). However the cells do not undergo apoptosis to the same degree (Table 1), even though cells in high $\mathrm{K}^{+}$with $0.02 \mathrm{mM} \mathrm{Ca}^{2+}$ exhibit higher steady-state $\mathrm{O}_{2}^{-}$ levels (Figure $7 \mathrm{~b}$ ). Thus, increased $\mathrm{O}_{2}^{-}$may be necessary but not sufficient for apoptosis progression. It is possible that a combination of enhanced $\mathrm{O}_{2}^{-}$and a hyperpolarized plasma membrane are required.

Cytochrome $c$ release from mitochondria occurs during CGN apoptosis following 3-4 $\mathrm{h}$ of low $\mathrm{K}^{+}$exposure. $5,6,37,44$ The mechanism of release, whether by activation of the permeability transition pore ${ }^{6,45}$ or BAX association with mitochondria ${ }^{27}$ is unclear. In the present study, no significant change in oligomycin-insensitive proton leak was evident over $1-5 \mathrm{~h}$ of $\mathrm{K}^{+}$/serum deprivation (Figure 3 , Table 1 ), despite the ncreasing number of cells showing signs of apoptosis during this period (Table 1). This time frame is sufficient to elicit cytochrome $c$ release ${ }^{5,6}$ and BAX translocation to mitochondria. ${ }^{27}$ Therefore, BAX translocation to mitochondria is not associated with a permeability transition, ${ }^{45}$ although the decreased spare respiratory capacity (Figure 3, Table 1) would be consistent with partial release of cytochrome $c$ by outer membrane permeabilization.

While our data are consistent with $\mathrm{O}_{2}^{-}$playing a possible permissive role in CGN apoptosis, they do not provide a mechanism, other than to show that the elevated $\mathrm{O}_{2}^{-}$levels in low $\mathrm{K}^{+}$are not sufficient to cause mitochondrial dysfunction. In sympathetic ganglion neurons and CGNs, Bax translocation to mitochondria is proposed to increase ROS production, stimulating VDAC transformation to a pore large enough to allow cytochrome $c$ release. $^{36,37}$ This model seems unlikely given that $\mathrm{CGN} \mathrm{O}_{2}^{-}$levels increase within $30 \mathrm{~min}$ of low $\mathrm{K}^{+}$ exposure (Figure 7) while Bax translocation to mitochondria appears to take longer than this. ${ }^{27}$ In other systems, it has been suggested that $\mathrm{O}_{2}^{-}$may promote cytochrome $c$ release by involving VDAC but not the permeability transition pore. For example, in HepG2 cells, exogenously generated $\mathrm{O}_{2}^{-}$induces cytochrome $c$ release in a VDAC-dependent but Bax-independent manner, ${ }^{46}$ while isolated liver mitochondria can release cytochrome $c$ in an ROS-dependent manner. ${ }^{47,48}$ In both cases, mitochondrial membrane potential $\left(\Delta \psi_{\mathrm{m}}\right)$ loss was not necessary to observe cytochrome $c$ release. Therefore, we can speculate that the modest $\mathrm{O}_{2}^{-}$increase in CGNs may be permissive in apoptosis by facilitating VDAC-dependent, but PT pore-independent, cytochrome $c$ release.

In summary, the cellular energetics of CGNs are immediately affected by proapoptotic low $\mathrm{K}^{+}$media. Specifically, reduced $\left[\mathrm{Ca}^{2+}\right]_{\mathrm{c}}$ results in a $25-30 \%$ drop in mitochondrial respiration, due entirely to a decrease in cell ATP turnover. Sodium cycling remains fairly constant in high and low $\mathrm{K}^{+}$. Steady-state $\mathrm{O}_{2}^{-}$levels increase rapidly in low $\mathrm{K}^{+}$. This is not a consequence of mitochondrial hyperpolarization due to decreased ATP turnover, but may be the result of decreased $\left[\mathrm{Ca}^{2+}\right]_{\mathrm{c}}$. Quantitative cell-by-cell differences in low $\mathrm{K}^{+}$ steady-state $\mathrm{O}_{2}^{-}$levels are not important for the development of apoptosis. However, the $\mathrm{O}_{2}^{-}$increase may play a role in apoptosis, as hippocampal neurons that are immune to low $\mathrm{K}^{+}$apoptosis do not exhibit changes in $\mathrm{O}_{2}^{-}$. Neither reduced $\left[\mathrm{Ca}^{2+}\right]_{\mathrm{c}}$ nor reduced mitochondrial respiration are sufficient to account for apoptosis occurring in low $\mathrm{K}^{+}$. Mitochondrial 

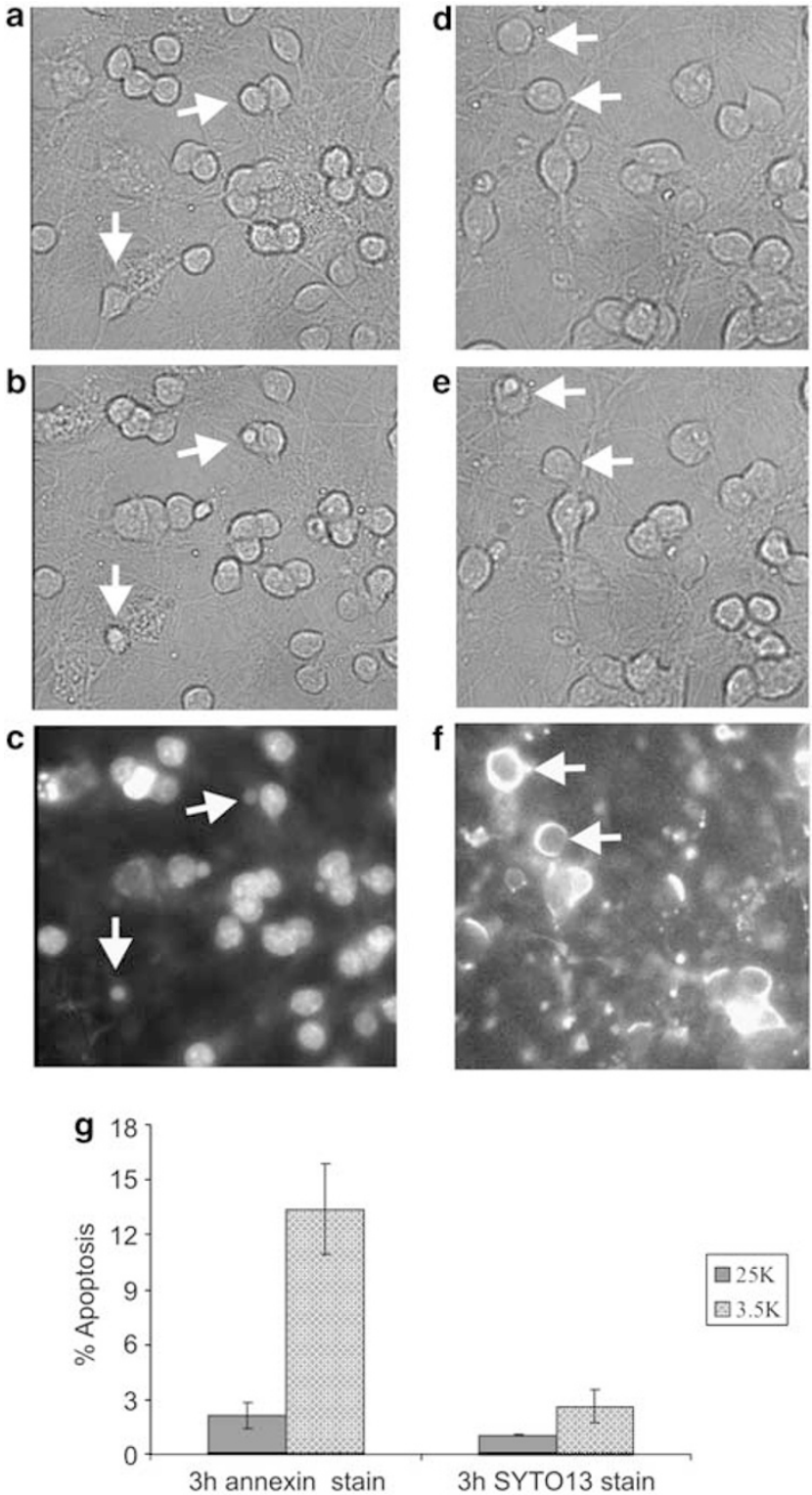

Figure 9 Apoptotic cells after $3 \mathrm{~h}$ low $\mathrm{K}^{+}$. Experiments were performed as described in Figure 1, except that after $3 \mathrm{~h}$ perfusion in standard low $\mathrm{K}^{+}$media, cells were either stained with SYTO13 (c) or with annexin V (f) as described in Materials and Methods. (a-c) are representative images from one experiment, with (a) the initial transmission image in standard high $\mathrm{K}^{+}$media, (b) the final transmission image after exposure to standard low $\mathrm{K}^{+}$media, and (c) the corresponding field stained with SYTO13. (d-f) are corresponding images from an experiment in which cells were stained with annexin V. Arrows illustrate cells considered apoptotic. (g) Quantitative assessment of percentage apoptotic cells by SYTO13 and annexin V staining after $3 \mathrm{~h}$ in standard low $\mathrm{K}^{+}$media. In most experiments, at least three random fields ( $>250$ total cells counted) were selected and scored for staining indicative of apoptosis. Data are mean + S.E.M. of four (low K ${ }^{+}$annexin stain), nine (low $\mathrm{K}^{+}$SYT013 stain), or three (high $\mathrm{K}^{+}$ annexin stain) experiments. Data for cells in high $\mathrm{K}^{+}$stained with SYTO13 are mean \pm S.D. of two experiments; in these two experiments cells were perfused with $25 \mathrm{~K}$ plus $0.4 \% \mathrm{BSA}$ rather than the standard high $\mathrm{K}^{+}$media

respiration remained constant over $5 \mathrm{~h}$ low $\mathrm{K}^{+}$, despite an increasing number of apoptotic cells, suggesting that dysfunction is not an early event necessary for progression of apoptosis.

\section{Materials and Methods}

\section{Reagents}

$\mathrm{TMRM}^{+}$, DHE, annexin V-R-phycoerythrin conjugate and SYTO13 were from Molecular probes (Eugene, OR, USA). FURA PE3 AM was from Tef Labs (Austin, TX, USA). BTx and TTX were from Calbiochem (La Jolla, $\mathrm{CA}$, USA). Dialyzed fetal bovine serum (FBS) $(10 \mathrm{kDa})$ was from Hyclone (Logan, UT, USA).

\section{CGN preparation and indicator loading}

Rat pups (5-7 days old) were killed by decapitation. Cerebella were dissected and minced in isolation buffer (phosphate-buffered saline supplemented with $13.9 \mathrm{mM}$ glucose, $3.2 \mathrm{mM} \mathrm{MgSO}$, and $3 \mathrm{mg} / \mathrm{ml}$ defatted BSA). Minced tissue was incubated in isolation buffer with $0.24 \mathrm{mg} / \mathrm{ml}$ trypsin with gentle agitation at $37^{\circ} \mathrm{C}$ up to $5 \mathrm{~min}$ then diluted five-fold in isolation buffer with $4.8 \mathrm{units} / \mathrm{ml}$ DNase. After centrifugation at room temperature $(5 \mathrm{~min}, 224 \times \mathrm{g})$, the cell pellet was triturated in isolation buffer with $6 \mathrm{mM} \mathrm{MgSO}{ }_{4}, 30 \mathrm{units} / \mathrm{ml}$ DNase and $50 \mu \mathrm{g} / \mathrm{ml}$ soybean trypsin inhibitor. The suspension was diluted in 2 volumes of minimal essential medium with $10 \% \mathrm{FBS}, 25 \mathrm{mM} \mathrm{KCl}$ and $30 \mathrm{mM}$ glucose (cell culture media) then centrifuged $3 \mathrm{~min}, 224 \times \mathrm{g}$. After resuspension of cells in culture media, large clumps were removed by passing through a $70 \mu \mathrm{m}$ filter. Cells were attached to $22 \times 40 \mathrm{~mm}$ coverslips previously coated with polyethyleneimine, then maintained at $37^{\circ} \mathrm{C}$ in a $95 / 5 \%$ air/ $/ \mathrm{CO}_{2}$ incubator and used after $6-9$ days in culture. Prior to experiments, cells were loaded with 2-3 $\mu \mathrm{M}$ FURA PE3 AM and $0.3 \mathrm{nM} \mathrm{TMRM}^{+}$for $80-110$ min in cell culture media. Under these conditions, $\mathrm{TMRM}^{+}$fluorescence was in nonquench mode ${ }^{49}$ meaning that a decrease in either $\Delta \psi_{\mathrm{p}}$ or $\Delta \psi_{\mathrm{m}}$ is reflected in a decrease in whole-cell fluorescence. For experiments using DHE, $\mathrm{TMRM}^{+}$was omitted.

\section{Hippocampal neuron preparation}

Primary hippocampal neurons were prepared from 1-2 pairs of E18 rat hippocampi (BrainBits ${ }^{\mathrm{TM}}$, LLC, Springfield, IL, USA) by papain dissociation and gentle trituration. Briefly, hippocampi were washed in $2 \mathrm{ml}$ of Hibernate $^{\mathrm{TM}}$ medium (BrainBits ${ }^{\mathrm{TM}}$ ) and then digested with $2 \mathrm{mg} / \mathrm{ml}$ papain (Worthington) in Hibernate ${ }^{\mathrm{TM}}$ for $30 \mathrm{~min}$ at $37^{\circ} \mathrm{C}$. Tissue was dispersed manually by 5-7 strokes with a $1 \mathrm{ml}$ pipette and $1.3-2.0 \times 10^{6}$ cells were plated onto poly-D-lysine-coated $22 \times 40 \mathrm{~mm}$ glass coverslips in Neurobasal medium (Invitrogen) containing B27 supplement, $0.5 \mathrm{mM}$ glutamine, $25 \mu \mathrm{M}$ glutamate, $1 \% \mathrm{FBS}$, and $1 \%$ penicillin/streptomycin. Neurons were maintained at $37^{\circ} \mathrm{C}$ in an incubator with a humidified atmosphere of $5 \% \mathrm{CO}_{2} / 95 \%$ air. On day 4 after plating, half of the medium was replaced with fresh medium lacking glutamate and serum. Half of the medium was replaced in this way every 3-4 days subsequent to day 4 and neurons were used at 11 days in vitro.

\section{Monitoring population respiration and imaging individual cells for indicator dyes}

A cell respirometer we developed was used to determine neuron oxygen consumption during imaging experiments. ${ }^{9}$ Coverslip-attached neurons $\left(3 \times 10^{6}\right)$ were assembled in an RC-30 imaging chamber (Warner Instruments, Hamden, CT, USA) with a $250 \mu \mathrm{m}$ gasket (yielding a chamber volume of $130 \mu$ l) then attached to the perfusion system. The chamber and associated tubing was mounted on an Olympus IX70 

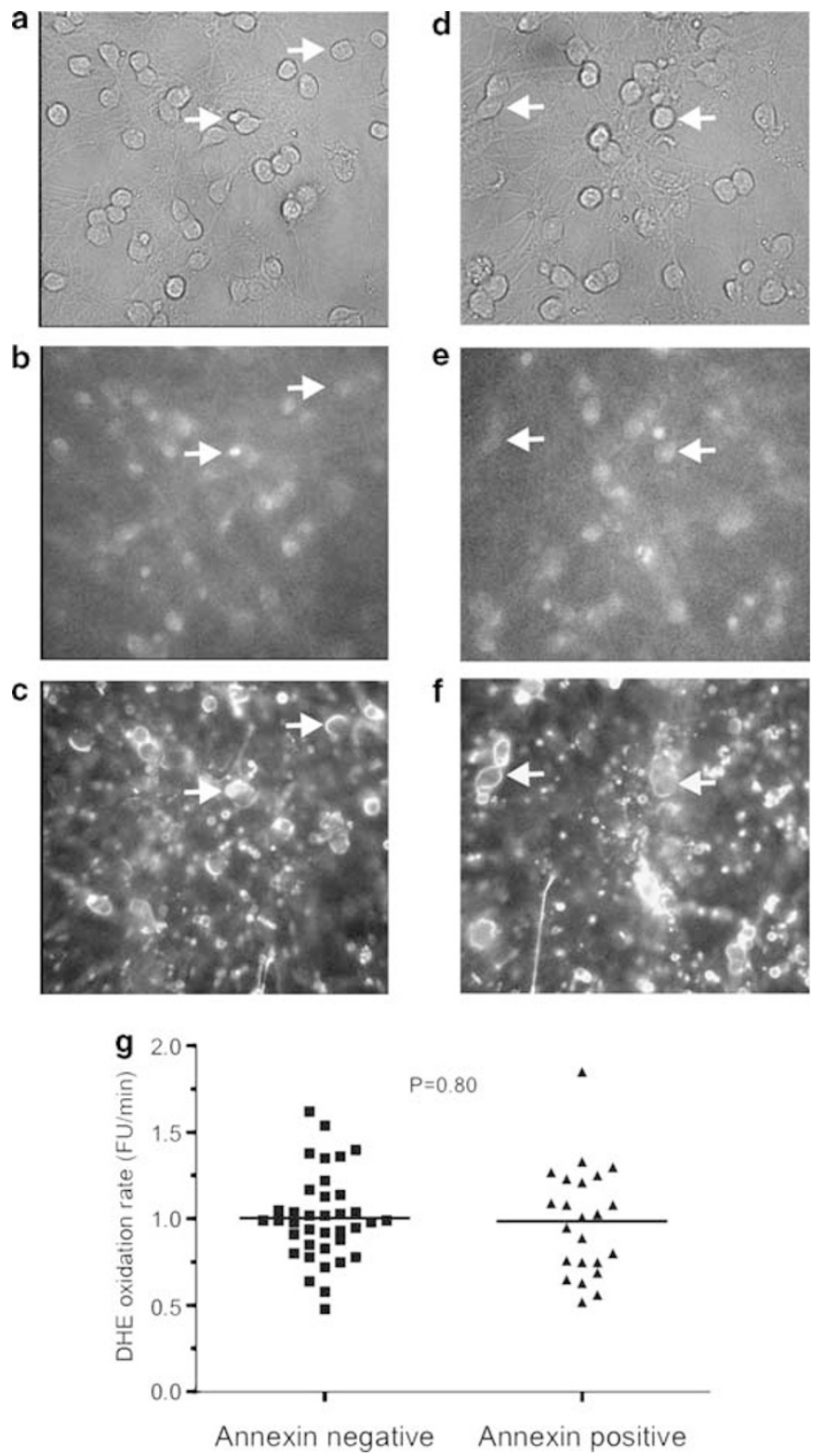

Figure 10 Steady-state superoxide levels do not differ between apoptotic and nonapoptotic CGNs. Cells were perfused $1 \mathrm{~h}$ in standard low $\mathrm{K}^{+}$media. Steady-state $\mathrm{O}_{2}^{-}$levels in individual cells were determined over the next $3 \mathrm{~h}$ by perfusion with low $\mathrm{K}^{+}$media plus $0.2 \mu \mathrm{M} \mathrm{DHE}$. Cells were then stained with annexin $\mathrm{V}$ as described in Figure 9. (a-c) and (d-f) are images from two experiments after $4 \mathrm{~h} \mathrm{low} \mathrm{K}{ }^{+}$. (a) and (d) show sections of the fields followed over $4 \mathrm{~h}$. (b and $\left.\mathbf{e}\right)$ are ethidium fluorescence images from the oxidation of DHE over the final $3 \mathrm{~h}$. (c and $\mathbf{f}$ ) are the same cells stained with annexin $\mathrm{V}$ after the final ethidium images were taken. Arrows illustrate example cells considered apoptotic. (g) Regions of interest were scored as annexin positive or negative, corresponding to apoptotic or nonapoptotic cells. DHE oxidation rate for each region was determined by linear regression as illustrated in Figure 7. By Student's paired $t$-test, DHE oxidation rate was not different between annexin positive and negative cells ( $n=3$ independent experiments)

inverted epifluorescence microscope equipped with a $\times 40$ oil-immersion objective. A miniature flow-through polarographic oxygen electrode (Microelectrodes, Inc., Bedford, NH, USA) placed downstream to the chamber was used to monitor cell respiration on a chart recorder. Electrode was calibrated using air-saturated buffer and buffer equilibrated with $50 \%$ air $/ 50 \%$ nitrogen, assuming that air-saturated buffer contains $351 \mathrm{nmol} \mathrm{O} / \mathrm{ml}$ at $37^{\circ} \mathrm{C}$. ${ }^{9}$ Buffer flow rate, typically $20-60 \mu \mathrm{l} / \mathrm{min}$, was set using a downstream peristaltic pump. The standard high $\mathrm{K}^{+}$perfusion medium contained (in $\mathrm{mM}$ ) $100 \mathrm{NaCl}, 25 \mathrm{KCl}, 20 \mathrm{TES}, 15$ glucose, 1.3 $\mathrm{MgCl}_{2}, 1.3 \mathrm{CaCl}_{2}, 1.2 \mathrm{Na}_{2} \mathrm{SO}_{4}, 0.4 \mathrm{KH}_{2} \mathrm{PO}_{4}, 0.2 \mathrm{NaHCO}_{3}, 10 \%$ dialyzed,

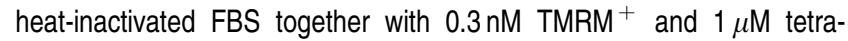
phenylboron, $\mathrm{pH} 7.3$ at $37^{\circ} \mathrm{C}$. The standard low $\mathrm{K}^{+}$perfusion medium differed by having $125 \mathrm{mM} \mathrm{NaCl}, 3.5 \mathrm{mM} \mathrm{KCl}$, and $0.4 \%$ fatty acid-free BSA as protein replacement for FBS. Variations of these standard buffers are specified in Results. In preliminary experiments, it was found that $0.4 \%$ BSA buffers required a greater concentration of FCCP $(9 \mu \mathrm{M})$ than $10 \%$ serum buffers $(3 \mu \mathrm{M})$ to achieve maximal respiration. BSA was included in the serum-free perfusions to control for nonspecific protein effects and because the efficacy of some mitochondrial inhibitors are affected by the presence of albumin and other serum proteins. The typical concentration 

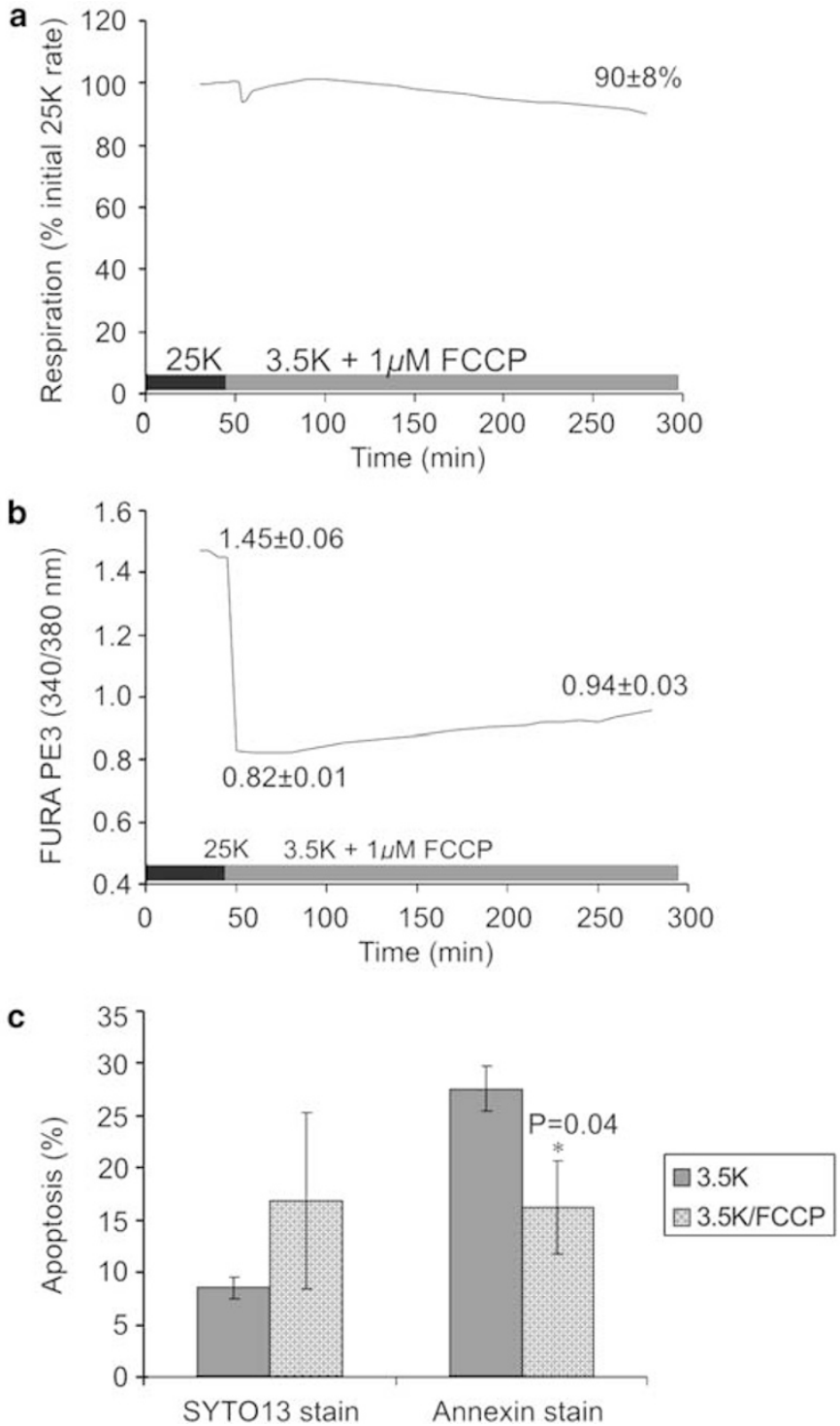

Figure 11 Apoptosis progression in low $\mathrm{K}^{+}$appears unaffected by maintaining constant mitochondrial respiration. Cells were switched from the standard high $\mathrm{K}^{+}$ media $(25 \mathrm{~K})$ to a low $\mathrm{K}^{+}$media supplemented with $1 \mu \mathrm{M}$ FCCP $(3.5 \mathrm{~K}+1 \mu \mathrm{M} \mathrm{FCCP})$ to maintain constant mitochondrial respiration (a). With inclusion of FCCP, cells showed normal cytoplasmic $\mathrm{Ca}^{2+}$ response to low $\mathrm{K}^{+}(\mathbf{b})$, indicating that this amount of FCCP did not affect ATP levels sufficiently to impair $\mathrm{Ca}^{2+}$ homeostasis. After $4 \mathrm{~h}$ low $\mathrm{K}^{+}$with FCCP, cells were SYTO13 stained, then annexin $\mathrm{V}$ stained $(n=3)$, and compared to standard $4 \mathrm{~h} \mathrm{low} \mathrm{K}^{+}$experiments where cells were either stained with SYTO13 $(n=5)$ or annexin V $(n=3)$ (c). Inclusion of FCCP did not significantly affect apoptosis by SYTO13 stain, but did significantly reduce the number of annexin V-stained cells

of albumin in undiluted serum is $35-50 \mathrm{~g} / \mathrm{l}$, with the total protein in serum being $60-80 \mathrm{~g} / \mathrm{l}$. With the serum diluted to $10 \%$ in these experiments, albumin should be about $0.4 \%$ and total protein about $0.7 \%$. Albumin was controlled because it is the main protein that will affect FCCP, oligomycin, and other mitochondrial inhibitors, although $0.4 \%$ BSA required more FCCP than $10 \%$ serum to achieve maximal respiration. As such the albumin content present in the BSA-containing buffers was probably greater than in buffers with serum, but the total protein present in the two conditions is probably similar.

The microscope was equipped with an Olympus Ultraview digital imaging system. TMRM ${ }^{+}$and FURA PE3 were excited sequentially at 545,340 , and $380 \mathrm{~nm}$ using a Spectramaster monochromator. The emission from both fluorophores was collected through a 73100 bs dichroic and 73101 dual band emission filter.

\section{Steady-state cell superoxide levels}

Stock $1 \mathrm{mM}$ DHE in DMSO was stored under $\mathrm{N}_{2}$ with a small amount of cation exchanger to minimize contaminating ethidium. Steady-state superoxide $\left(\mathrm{O}_{2}^{-}\right)$levels were determined along with respiration rates by adding $0.2 \mu \mathrm{M}$ DHE to the perfusion buffers just before use. TMRM ${ }^{+}$ and tetraphenylboron were omitted from all buffers. After $20 \mathrm{~min}$ initial perfusion period with DHE, cells were imaged at $5 \mathrm{~min}$ intervals for $50 \mathrm{~min}$. The fluorescence increase remained linear over these experiments, indicating DNA did not saturate with ethidium.

\section{Assessing cells undergoing apoptosis}

At the end of some experiments, cells were either stained with SYTO13 for nucleic acid morphology, or with annexin $\mathrm{V}$ for detecting phosphatidylserine 
Non-apoptotic
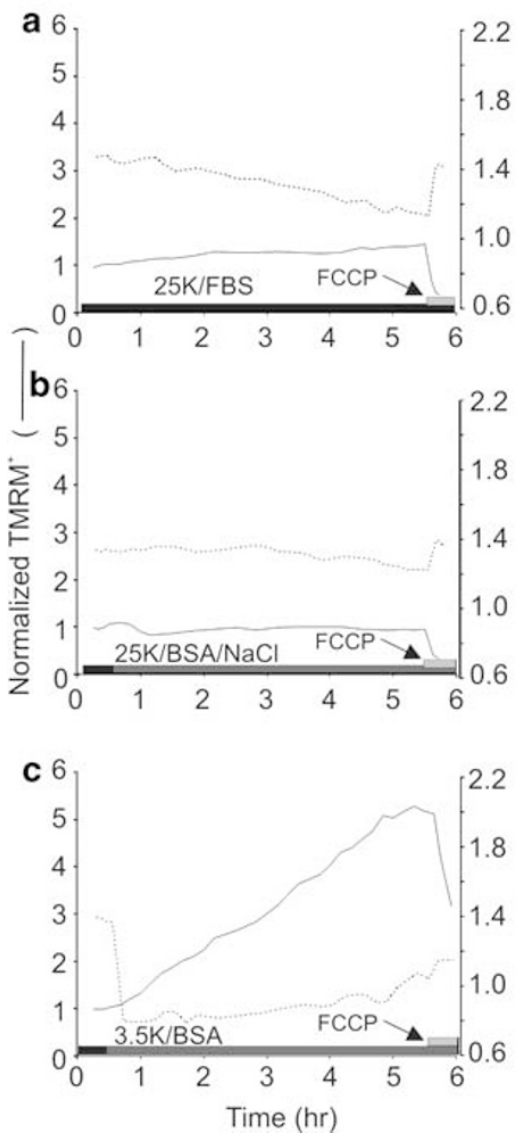

Apoptotic
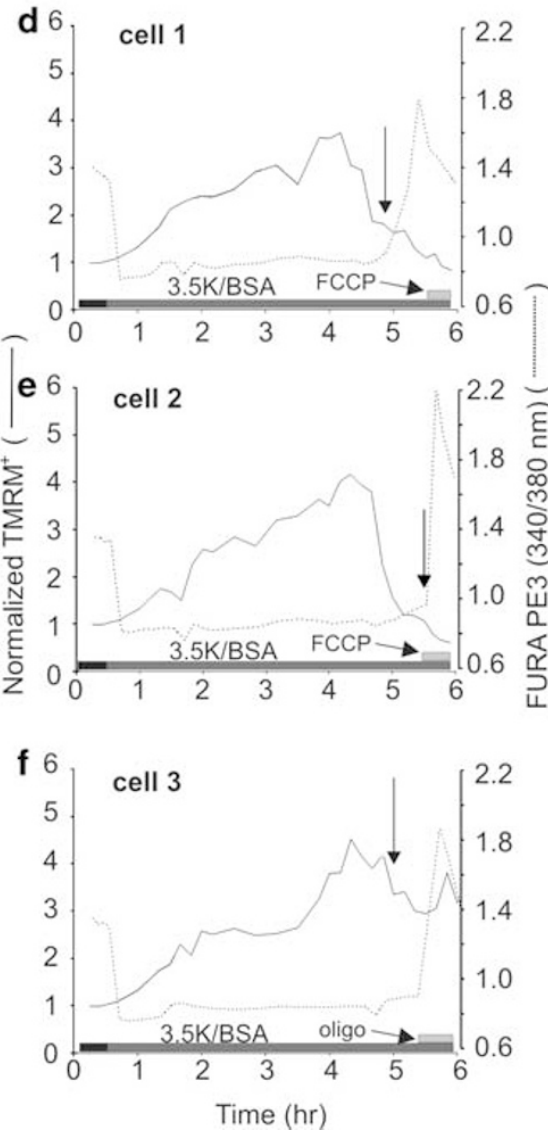

Figure 12 Cells undergoing apoptosis do not retain accumulated TMRM ${ }^{+}$. Single-cell TMRM ${ }^{+}$and FURA PE3 fluorescence were analyzed from the experiments described in Table 1, with images taken every 10-20 min. Fluorescence from nonapoptotic cells were averaged, but because of the stochastic nature of apoptosis progression, data from these cells are shown individually. The average responses from 12-34 nonapoptotic CGN somas during $5 \mathrm{~h}$ perfusion in $25 \mathrm{~K} / \mathrm{FBS}$ (a), 25K/BSA/ $\mathrm{NaCl}(\mathbf{b})$, and 3.5K/BSA (c) are shown, followed by FCCP addition as indicated. The time at which cells were exposed to the test buffer is indicated by the change in bar color from black to grey. Representative single-cell soma responses from apoptotic CGNs perfused in 3.5K/BSA (d-f) are provided, with effects of both FCCP (d, e) and oligomycin (f) shown. The steady increase in TMRM ${ }^{+}$accumulation in $3.5 \mathrm{~K} / \mathrm{BSA}$ is a consequence of plasma membrane hyperpolarization in this medium. The subsequent decrease in cells that apoptose (d-f) indicates depolarization of either the plasma or mitochondrial membrane. Vertical arrows are the point where cells first exhibited morphological signs of apoptosis (i.e., cell and/or nuclear condensation), and these cells were also annexin positive at the end of the experiment

externalization. For SYTO13 staining, cells were perfused $5-10$ min with either the high or low $\mathrm{K}^{+}$standard buffer (see above) containing $0.5 \mu \mathrm{M}$ SYTO13. Staining was detected using $545 \mathrm{~nm}$ excitation. Two to four random fields were imaged, and cells exhibiting punctate and/or discrete high intensity staining were considered apoptotic.

For annexin $\mathrm{V}$ staining, cells were first washed $5-8 \mathrm{~min}$ by perfusion with annexin buffer, containing (in $\mathrm{mM}$ ): $140 \mathrm{NaCl}, 3.5 \mathrm{KCl}, 10 \mathrm{TES}, 2.5$ $\mathrm{CaCl}_{2}$, and 5 glucose. Cells were stained $7-15 \mathrm{~min}$ in the same buffer with 1:500 annexin $\mathrm{V}$ (R-phycoerythrin conjugate) then washed briefly in annexin buffer and visualized using $470 \mathrm{~nm}$ excitation. Cells having partial to complete plasma membrane staining were considered apoptotic.

For $5 \mathrm{~h}$ perfusion experiments, apoptosis occurring during the experiment was estimated by cell morphology changes using transmission images. Cells that began to shrink in size and exhibit condensed nuclei were considered apoptotic (see Figure 9). Because the same field was followed throughout the entire experiment, the percentage of cells undergoing apoptosis during the experiment was based on a single field, typically containing 60-120 cells. Dead, nonrespiring cells were distinguished from apoptotic cells by monitoring the integrity of the plasma membrane. The plasma membrane was considered intact if the cell retained FURA PE3. Thus, morphologically apoptotic cells retaining FURA PE3 were considered viable and contributing to the population respiration.

\section{Acknowledgements}

This work was supported by the National Institutes of Health grant R01 AG21440. We thank B Polster for preparation of hippocampal neurons, and $A$ Wang and $L$ Kirk for preparation of cerebellar granule neurons.

\section{References}

1. Lauritzen I, Zanzouri M, Honoré E, Duprat F, Ehrengruber MU, Lazdunski M and Patel AJ (2003) $\mathrm{K}^{+}$-dependent cerebellar granule neuron apoptosis - role of task leak $\mathrm{K}^{+}$channels. J. Biol. Chem. 278: 32068-32076

2. Herlitze S, Xie M, Han J, Hümmer A, Melnik-Martinez KV, Moreno RL and Mark MD (2003) Targeting mechanisms of high voltage-activated $\mathrm{Ca}^{2+}$ channels. J. Bioenerg. Biomembr. 35: 621-637 
3. Patel AJ and Lazdunski M (2004) The 2P-domain $\mathrm{K}^{+}$channels: role in apoptosis and tumorigenesis 8. Pflugers Arch. 448: 261-273

4. Atlante A, Gagliardi S, Marra E and Calissano P (1998) Neuronal apoptosis in rats is accompanied by rapid impairment of cellular respiration and is prevented by scavengers of reactive oxygen species. Neurosci. Lett. 245: 127-130

5. Bobba A, Atlante A, Giannattasio S, Sgaramella G, Calissano P and Marra E (1999) Early release and subsequent caspase-mediated degradation of cytochrome $c$ in apoptotic cerebellar granule cells. FEBS Lett. 457: 126-130

6. Linseman DA, Phelps RA, Bouchard RJ, Le SS, Laessig TA, McClure ML and Heidenreich KA (2002) Insulin-like growth factor-I blocks Bcl-2 interacting mediator of cell death (Bim) induction and intrinsic death signaling in cerebellar granule neurons 13. J. Neurosci. 22: 9287-9297

7. Miller TM, Moulder KL, Knudson CM, Creedon DJ, Deshmukh M, Korsmeyer SJ and Johnson Jr EM (1997) Bax deletion further orders the cell death pathway in cerebellar granule cells and suggests a caspase-independent pathway to cell death. J. Cell Biol. 139: 205-217

8. Polster BM and Fiskum G (2004) Mitochondrial mechanisms of neural cell apoptosis. J. Neurochem. 90: 1281-1289

9. Jekabsons MB and Nicholls DG (2004) In situ respiration and bioenergetic status of mitochondria in primary cerebellar granule neuronal cultures exposed continuously to glutamate. J. Biol. Chem. 279: 32989-33000

10. Gonzalvez F, Pariselli F, Dupaigne P, Budihardjo I, Lutter M, Antonsson B, Diolez P, Manon S, Martinou JC, Goubern M, Wang X, Bernard S and Petit PX (2005) tBid interaction with cardiolipin primarily orchestrates mitochondrial dysfunctions and subsequently activates Bax and Bak. Cell Death Differ. 12 614-626

11. Rostovtseva TK, Antonsson B, Suzuki M, Youle RJ, Colombini M and Bezrukov SM (2004) Bid, but not Bax, regulates VDAC channels. J. Biol. Chem. 279: $13575-13583$

12. Vander Heiden MG, Chandel NS, Li XX, Schumacker PT, Colombini M and Thompson CB (2000) Outer mitochondrial membrane permeability can regulate coupled respiration and cell survival. Proc. Natl. Acad. Sci. USA 97: 4666-4671

13. Hammerman PS, Fox CJ and Thompson CB (2004) Beginnings of a signaltransduction pathway for bioenergetic control of cell survival. Trends Biochem. Sci. 29: 586-592

14. Vesce S, Jekabsons MB, Johnson-Cadwell LI and Nicholls DG (2005) Neuronal glutathione depletion increases vulnerability to glutamate by restricting mitochondrial ATP export. J. Biol. Chem. 280: 38720-38728

15. Scott ID and Nicholls DG (1980) Energy transduction in intact synaptosomes: influence of plasma- membrane depolarization on the respiration and membrane potential of internal mitochondria determined in situ. Biochem. J. 186: 21-33

16. Atchison WD, Luke VS, Narahashi T and Vogel SM (1986) Nerve membrane sodium channels as the target site of brevetoxins at neuromuscular junctions. Br. J. Pharmacol. 89: 731-738

17. Campbell DT (1992) Large and small vertebrate sensory neurons express different $\mathrm{Na}$ and $\mathrm{K}$ channel subtypes. Proc. Natl. Acad. Sci. USA 89: 9569-9573

18. Leppanen L and Stys PK (1997) Ion transport and membrane potential in CNS myelinated axons I. Normoxic conditions. J. Neurophysiol. 78: 2086-2094

19. Valencia A and Morán J (2001) Role of oxidative stress in the apoptotic cell death of cultured cerebellar granule neurons. J. Neurosci. Res. 64: 284-297

20. Korshunov SS, Skulachev VP and Starkov AA (1997) High protonic potential actuates a mechanism of production of reactive oxygen species in mitochondria. FEBS Lett. 416: 15-18

21. Starkov AA, Polster BM and Fiskum G (2002) Regulation of hydrogen peroxide production by brain mitochondria by calcium and Bax. J. Neurochem. 83: $220-228$

22. Lambert AJ and Brand MD (2004) Superoxide production by NADH: ubiquinone oxidoreductase (complex I) depends on the $\mathrm{pH}$ gradient across the mitochondrial inner membrane. Biochem. J. 382: 511-517

23. Nicotera $P$ and Leist $M$ (1997) Energy supply and the shape of death in neurons and lymphoid cells. Cell Death Differ. 4: 435-442

24. Castiglione M, Spinsanti $P$, lacovelli L, Lenti L, Martini F, Gradini R, Gerevini VD, Caricasole A, Caruso A, De Maria R, Nicoletti F and Melchiorri D (2004) Activation of Fas receptor is required for the increased formation of the disialoganglioside GD3 in cultured cerebellar granule cells committed to apoptotic death. Neuroscience 126: 889-898
25. Harris C, Maroney AC and Johnson Jr EM (2002) Identification of JNKdependent and -independent components of cerebellar granule neuron apoptosis. J. Neurochem. 83: 992-1001

26. McGinnis KM, Gnegy ME and Wang KK (1999) Endogenous Bax translocation in SH-SY5Y human neuroblastoma cells and cerebellar granule neurons undergoing apoptosis. J. Neurochem. 72: 1899-1906

27. Linseman DA, Butts BD, Precht TA, Phelps RA, Le SS, Laessig TA, Bouchard RJ, Florez-McClure ML and Heidenreich KA (2004) Glycogen synthase kinase3beta phosphorylates Bax and promotes its mitochondrial localization during neuronal apoptosis. J. Neurosci. 24: 9993-10002

28. Alavez S, Pedroza D and Morán J (2003) Mechanisms of cell death by deprivation of depolarizing conditions during cerebellar granule neurons maturation. Neurochem. Int. 43: 581-590

29. Schulz JB, Weller M and Klockgether T (1996) Potassium deprivation-induced apoptosis of cerebellar granule neurons: A sequential requirement for new mRNA and protein synthesis, ICE-like protease activity, and reactive oxygen species. J. Neurosci. 16: 4696-4706

30. Tanabe H, Eguchi Y, Shimizu S, Martinou JC and Tsujimoto Y (1998) Deathsignalling cascade in mouse cerebellar granule neurons. Eur. J. Neurosci. 10: 1403-1411

31. Atlante A, Giannattasio S, Bobba A, Gagliardi S, Petragallo V, Calissano P, Marra E and Passarella $S$ (2005) An increase in the ATP levels occurs in cerebellar granule cells en route to apoptosis in which ATP derives from both oxidative phosphorylation and anaerobic glycolysis. Biochim. Biophys. Acta 1708: 50-62

32. Martin-Romero FJ, Garcia-Martin E and Gutierrez-Merino C (2002) Inhibition of oxidative stress produced by plasma membrane $\mathrm{NADH}$ oxidase delays lowpotassium-induced apoptosis of cerebellar granule cells. J. Neurochem. 82: 705-715

33. Atlante A, Bobba A, Calissano P, Passarella S and Marra E (2003) The apoptosis/necrosis transition in cerebellar granule cells depends on the mutual relationship of the antioxidant and the proteolytic systems which regulate ROS production and cytochrome $c$ release en route to death. J. Neurochem. 84: 960-971

34. Tabuchi A, Funaji K, Nakatsubo J, Fukuchi M, Tsuchiya T and Tsuda M (2003) Inactivation of aconitase during the apoptosis of mouse cerebellar granule neurons induced by a deprivation of membrane depolarization. J. Neurosci. Res. 71: 504-515

35. Starkov AA and Fiskum $\mathrm{G}$ (2003) Regulation of brain mitochondrial $\mathrm{H}_{2} \mathrm{O}_{2}$ production by membrane potential and $\mathrm{NAD}(\mathrm{P}) \mathrm{H}$ redox state. J. Neurochem. 86: 1101-1107

36. Kirkland RA, Windelborn JA, Kasprzak JM and Franklin JL (2002) A Baxinduced pro-oxidant state is critical for cytochrome $c$ release during programmed neuronal death. J. Neurosci. 22: 6480-6490

37. Kirkland RA and Franklin JL (2003) Bax, reactive oxygen, and cytochrome $c$ release in neuronal apoptosis. Antioxid. Redox. Signal. 5: 589-596

38. Liu YB, Fiskum $G$ and Schubert D (2002) Generation of reactive oxygen species by the mitochondrial electron transport chain. J. Neurochem. 80: $780-787$

39. Nicholls DG (1977) The effective proton conductances of the inner membrane of mitochondria from brown adipose tissue: dependency on proton electrochemical gradient. Eur. J. Biochem. 77: 349-356

40. Connor JA, Tseng HY and Hockberger PE (1987) Depolarization- and transmitter-induced changes in intracellular $\mathrm{Ca}^{2+}$ of rat cerebellar granule cells in explant culture. J. Neurosci. 7: 1384-1400

41. Pocock JM, Cousin MA and Nicholls DG (1993) The calcium channel coupled to glutamate exocytosis from cerebellar granule cells is inhibited by the spider toxin Aga-Gl. Neuropharmacology 32: 1185-1194

42. Galli C, Meucci O, Scorziello A, Werge TM, Calissano P and Schettini G (1995) Apoptosis in cerebellar granule cells is blocked by high $\mathrm{KCl}$, forskolin, and IGF1 through distinct mechanisms of action: the involvement of intracellular calcium and RNA synthesis. J. Neurosci. 15: 1172-1179

43. Nicholls DG and Scott ID (1980) The regulation of brain mitochondrial calcium-ion transport: the role of ATP in the discrimination between kinetic and membrane-potential-dependent Ca efflux mechanisms. Biochem. J. 186: 833-839

44. Bobba A, Canu N, Atlante A, Petragallo V, Calissano P and Marra E (2002) Proteasome inhibitors prevent cytochrome $c$ release during apoptosis but not in excitotoxic death of cerebellar granule neurons. FEBS Lett. 515: 8-12 
45. Precht TA, Phelps RA, Linseman DA, Butts BD, Le SS, Laessig TA, Bouchard RJ and Heidenreich KA (2005) The permeability transition pore triggers Bax translocation to mitochondria during neuronal apoptosis. Cell Death. Differ. 12: 255-265

46. Madesh M and Hajnoczky G (2001) VDAC-dependent permeabilization of the outer mitochondrial membrane by superoxide induces rapid and massive cytochrome $c$ release. J. Cell Biol. 155: 1003-1015

47. Petrosillo G, Ruggiero FM, Pistolese M and Paradies G (2004) $\mathrm{Ca}^{2+}$-induced reactive oxygen species production promotes cytochrome $c$ release from rat liver mitochondria via mitochondrial permeability transition (MPT)-dependent and MPT-independent mechanisms: role of cardiolipin. J. Biol. Chem. 279: 53103-53108

48. Petrosillo G, Ruggiero FM and Paradies G (2003) Role of reactive oxygen species and cardiolipin in the release of cytochrome $c$ from mitochondria. FASEB J. 17: 2202-2208

49. Ward MW, Rego AC, Frenguelli BG and Nicholls DG (2000) Mitochondria membrane potential and glutamate excitotoxicity in cultured cerebellar granule cells. J. Neurosci. 20: 7208-7219 